\title{
A life cycle assessment of poly-hydroxybutyrate extraction from microbial biomass using dimethyl carbonate
}

Righi, Serena; Baioli, Filippo; Samorì , Chiara; Galletti, Paola; Tagliavini, Emilio; Stramigioli, Carlo; Tugnoli, Alessandro; Fantke, Peter

Published in:

Journal of Cleaner Production

Link to article, DOI:

10.1016/j.jclepro.2017.08.227

Publication date:

2017

Document Version

Peer reviewed version

Link back to DTU Orbit

Citation (APA):

Righi, S., Baioli, F., Samorì , C., Galletti, P., Tagliavini, E., Stramigioli, C., Tugnoli, A., \& Fantke, P. (2017). A life cycle assessment of poly-hydroxybutyrate extraction from microbial biomass using dimethyl carbonate. Journal of Cleaner Production, 168, 692-707. https://doi.org/10.1016/j.jclepro.2017.08.227

\section{General rights}

Copyright and moral rights for the publications made accessible in the public portal are retained by the authors and/or other copyright owners and it is a condition of accessing publications that users recognise and abide by the legal requirements associated with these rights.

- Users may download and print one copy of any publication from the public portal for the purpose of private study or research.

- You may not further distribute the material or use it for any profit-making activity or commercial gain

- You may freely distribute the URL identifying the publication in the public portal 


\title{
A life cycle assessment of poly-hydroxybutyrate extraction from microbial biomass using dimethyl carbonate
}

\author{
Serena Righi ${ }^{1,2}$, Filippo Baioli ${ }^{2}$, Chiara Samorì ${ }^{1,2}$, Paola Galletti ${ }^{1,2}$, Emilio Tagliavini ${ }^{1,2}$, Carlo \\ Stramigioli ${ }^{3}$, Alessandro Tugnoli ${ }^{3}$, Peter Fantke ${ }^{4}$ \\ ${ }^{1}$ CIRI Energia e Ambiente, U.O. Biomasse, Alma Mater Studiorum - University of Bologna, via \\ S. Alberto 163, 48123 Ravenna, Italy \\ ${ }^{2}$ CIRSA Centro Interdipartimentale di Ricerca per le Scienze Ambientali, Alma Mater Studiorum \\ - University of Bologna, via dell'Agricoltura 5, 48123 Ravenna, Italy \\ ${ }^{3}$ LISES - Dipartimento di Ingegneria Civile, Chimica, Ambientale e dei Materiali (DICAM), Alma \\ Mater Studiorum - University of Bologna, via Terracini 28, 40131 Bologna, Italy \\ ${ }^{4}$ Quantitative Sustainability Division, Department of Management Engineering, Technical \\ University of Denmark, Bygningstorvet 116, 2800 Kgs. Lyngby, Denmark \\ Email: serena.righi2@unibo.it
}




\begin{abstract}
Poly-hydroxyalkanoates are an example of biodegradable and biocompatible polymers, produced from renewable raw materials. With respect to other bioplastics the market share of poly-hydroxyalkanoates is still limited because of their commercial costs. To develop more costeffective processes, a multilevel approach is usually undertaken combining innovative, cheaper and more effective microbial cultivation with safe and cheap extraction and purification methodologies. This study assesses the potential life cycle environmental impacts related to a novel protocol poly-hydroxyalkanoates extraction based on dimethyl carbonate in comparison to the use of halogenated hydrocarbons (in particular 1,2 dicholoroethane). Four scenarios are analysed for the dimethyl carbonate protocol considering: extraction from microbial slurry or from dried biomass, and recovery by solvent evaporation or polymer precipitation. The life cycle assessment demonstrates that the environmental performances of dimethyl carbonate-based protocols are far better than those of the most comparative process using the halogenated hydrocarbons. The scenario that foresees the extraction of dried biomass and recovers solvent by evaporation appears to be the most promising in terms of environmental sustainability performance.
\end{abstract}

Keywords: bio-based polymers; bioplastics; poly-hydroxyalkanoates; environmental impact; environmental performance; ecodesign.

\title{
1. Introduction
}

Plastic materials from fossil sources play an important and pervasive role in our everyday life. However, the same characteristics of durability and resistance to degradation which account for their commercial and applicative success cause most of these synthetic plastic polymers to withstand the ocean and terrestrial ecosystems for years to decades or longer, affecting organisms at multiple trophic levels (Ojeda, 2013). The replacement of petroleum-based nonbiodegradable plastics with alternative bio-based materials that have comparable properties and that are more readily degradable after being discarded has become an industrial, social and environmental priority. The current annual global production capacity of bioplastics, including both biodegradable and bio-based plastics, is about $2 \mathrm{Mt}$ and a significant growth of the bioplastics market is expected in the next few years (European Bioplastic, 2015).

Among biopolymers, poly-hydroxyalkanoates (PHAs) have rapidly gained interest both in research and industry because they are greatly versatile, fully biodegradable and with properties similar to conventional plastics (Keshavarz and Roy, 2010; Vega-Castro et al., 2016; Dietrich et al., 2017). PHAs are linear polyesters produced by single (e.g. Cupriavidus necator) or mixed microbial consortia through aerobic fermentation of many carbon sources such as 
polysaccharides or lipids, to store carbon and energy. At present, approximately 150 different PHA monomers can be combined yielding materials with distinct physical properties as function of the monomer composition including properties similar to those of polypropylene and polyethylene, but with the advantage of being biodegradable, biocompatible and produced from renewable raw materials (Steinbüchel and Lütke-Eversloh, 2003). Thanks to this peculiar combination of suitable physical and mechanical properties and biodegradation abilities, PHAs could be used in packaging but also in biomedical applications as biodegradable carriers for drug release, disposable items, surgical pins, and wound dressings.

Poly-hydroxyalkanoates rank highly in terms of 'green design' but they can nonetheless exhibit relatively large environmental impacts and, if all life cycle phases are taken into consideration, the final environmental balance can be even worse than that of conventional polymers obtained from petroleum (Tabone et al., 2010).

Several studies report that the dominant contributions to energy requirement (and, consequently, environmental burden) in the production of PHAs are: i) the use of cultivated feedstock, such as corn and sugar cane, to obtain substrates like as glucose, methanol or acetic acid (Patel et al., 2005; Keshavarz and Roy, 2010), ii) the sterilization of fermentation equipment (Van Wegen et al., 1998); iii) the recovery of the intracellular polymer (Keshavarz and Roy, 2010; Rostkowski et al., 2012; Fernández-Dacosta et al. 2015). Persistent effort is being made to find environmental friendly feedstock, like as waste vegetable oil, wastewater, food scraps, waste oils, etc. (Heimersson et al., 2014; Anjum et al., 2016). In second point regards, research is continuing on mixed microbial culture instead of the more expensive and problematic pure culture (Hao et al., 2017; Montiel-Jarillo et al., 2017). As far as concerned the last point, a more environmentally benign PHAs recovery method that is less energy intensive and does not use harmful solvents appears one priority (Keshavarz and Roy, 2010; Rostkowski et al., 2012). In general, the recovery of intracellular PHAs can be accomplished via two processes: i) solvent extraction, or ii) digestion of the non-PHAs cellular matrix. The first process is currently mainly based on the use of chlorinated solvents (e.g. chloroform), able to dissolve the polymer in high quantity, and affording, at the same time, the highest levels of PHAs purity. The second process is based on the dissolution of cellular membranes by using alkaline/acidic solutions, sodium hypochlorite or surfactants, in order to release PHAs from cells. This process, however, does not usually yield high levels of purity, can affect the mechanical properties of the polymer and increase the recovery costs affecting wastewater treatment and re-use.

Samorì et al. (2015) have designed a new protocol for the extraction of poly-hydroxybutyrate (PHB) and various copolymers (e.g. poly-hydroxybutyrate-valerate, PHBHV) from single strains and mixed microbial consortia with a high content of polymer (74 and $40 \%$ wt $\%$, respectively) using as solvent dimethyl carbonate (DMC). DMC is an acyclic alkyl carbonate and it has become increasingly important in the chemical industry mainly because of its versatility as reagent and solvent, and its relatively low toxicity for human health and for the environment 
(Delledonne et al., 2001). This study therefore aims to assess the potential environmental impacts related to a production processes based on the protocol proposed by Samorì et al. (2015) in comparison to the extraction with halogenated. We apply an attributional Life Cycle Assessment (LCA) adopting a 'gate-to-gate' perspective: we start from the microbial biomass enriched in PHA and stop when the polymer is ready to be formed. Up to now, the DMC-based protocol has been developed only on a laboratory scale thus an industrial-scale production has been hypothesized. and this preliminary analysis of potential environmental impacts of a future industrial-scale production can provide useful information to better orient the development and scale-up activities.

\section{Materials and Methods}

\subsection{Extraction processes using dimethyl carbonate}

PHB is one of the most well-known and studied PHAs, therefore has been taken as the study polymer. The method is based on the solubilisation of PHB with dimethyl carbonate (DMC). The procedure can be applied directly to concentrated microbial slurries or to dry biomass, affording very high polymer recovery (>92\%) and excellent purity (>95\%).

The direct extraction from microbial slurry requires a biomass concentration of $100 \mathrm{~g} \mathrm{~L}^{-1}$. Such concentration was achieved by centrifuging and concentrating a pure microbial culture after the accumulation phase. The slurries were extracted with DMC for $1 \mathrm{~h}$ at $90{ }^{\circ} \mathrm{C}$. After that, DMC phase and the biomass slurry were centrifuged and separated, and the extracted polymer was recovered after (i) evaporation of DMC or (ii) precipitation with ethanol $(\mathrm{EtOH})$. The polymer recovery was very high in both cases (>96\%). The extraction from dried biomass requires a biomass to solvent ratio of $2.5 \%(\mathrm{w} / \mathrm{v})$. The biomass and the solvent were centrifuged and kept at $90^{\circ} \mathrm{C}$ for $4 \mathrm{~h}$. The residual biomass was then centrifuged and the polymer was recovered after (i) evaporating the solvent or (ii) the addition of $\mathrm{EtOH}$ and precipitation. In this case, the polymer recovery was above $92 \%$ in both recovery scenarios.

\subsection{Extraction processes using halogenated hydrocarbons}

Chlorinated solvents are the best performing organic solvents for solubilizing and recovering PHAs from microbial cells, therefore, an extraction with halogenated hydrocarbons has been chosen as comparison process. Among the patented processes, the US Patent 4324907 (Senior et al., 1982) has been selected for three reasons: 1) high PHA recovery (95\%); 2) data comprehensiveness; 3) similarity to DMC extraction process. In the patented process, an aqueous suspension of cells is spray-dried and then refluxed with 1,2-dichloroethane (DCE) at $83^{\circ} \mathrm{C}$ for solubilizing PHB. Finally, PHB is precipitated by adding a methanol/water mixture and 
filtered. The polymer purity is very high $(98 \%)$. Similar results are obtained using dichloromethane or chloroform instead of 1,2-dichloroethane in the PHB extraction process.

\subsection{Modelling and scale-up of the extraction processes}

Industrial scale production of PHB with DMC is not yet established, resulting in lack of direct input/output data for the LCl. Therefore, the extraction processes at industrial scale have been simulated by a preliminary design of the envisaged process plant based on the information available from the current lab-scale protocol. The scale-up was based on the principia of good engineering practice in scale-up of batch processes and equipment design (Sinnott, 1993; Bisio and Kabel, 1985; Zlokarnik, 2002). While it is recognized that the actual scale-up would require extensive research efforts, this simplified approach is considered adequate for the purpose of explorative LCA studies (Righi et al., 2011; Righi et al., 2016). The material and energy balances for the envisaged process flow diagram were quantified with the support of a Chemical Process Simulation (CPS) software (Aspen HYSYS ${ }^{\circledR}$ by Aspentech), and the main equipment units were preliminary sized on the basis of relevant scientific and technical references (Table 1). The extraction processes are composed by a series of equipment units: 1) centrifuges; 2) batch reaction vessels; 3) air dryers; 4) catalytic oxidizer; 5) pervaporation systems (only in the scenarios where the polymer is recovered with the addition of $\mathrm{EtOH}$ ). The equipments are different in dimensions and arrangement in base on the different scenarios (see Fig. 1).

$<$ Table 1>

$<$ Figure 1>

\subsection{Application of environmental life cycle assessment}

The goal of this study is to compare the environmental performance of the protocol proposed by Samorì et al. (2015) for the extraction of PHB with DMC from microbial cells with the environmental performance due to an alternative process using chlorinated solvents using LCA. A 'gate-to-gate' approach is used, and only the extraction process has been considered since the cultivation phase and the bioplastic product manufacture after the polymer extraction are assumed to be equivalent for all considered extraction processes. The system boundaries of the study include the following processes: 1) biomass preparation; 2) chemicals production; 3) PHB extraction; 4) chemicals recovery; 5) air emissions abatement; 6) solid waste management. Note that the microbial cells cultivation is not included in the system boundaries and that the processes downstream from cultivation are often the most cost and energy consuming (Fernández-Dacosta et al. 2015). The functional unit (FU) is defined as $1 \mathrm{~kg}$ of PHB ready for the product's manufacturing. 


\subsubsection{Scenarios description and assumptions}

Two different ways for extracting PHB with DMC have been analysed: a) extraction from dried biomass (Dry) and b) extraction from microbial slurry (Slurry). For each of the two extraction ways, two sub-scenarios have been evaluated, which differ in the polymer recovery strategy: 1) after evaporation of the solvent (Evap); or 2) after the addition of $\mathrm{EtOH}$ and precipitation (Precip). Each of the four resulting scenarios has been compared to the '1,2-dichloroethane scenario' which supplies the same quantity of PHB applying the patent of Senior et al. (1982) Table 2 shows the main features of each scenario.

The following cut-off rules and assumptions have been adopted: 1) electric consumption of apparatus for mass transferring, electric consumption of catalytic oxidizer, water consumption of cooling pumps have been omitted (the first two because only low contributions are expected, the last one because water is supposed to be extracted and then returned to the water stream); 2) only the operational phase has been considered, excluding equipment construction, maintenance and dismantling; 3) all electricity comes from the Italian national grid power (2014 reference year); 4) the purge factor of air dryers has been fixed to $0.2 \%$ (according to Hischier et al. (2005) on diffusive and fugitive emissions to air from production plants); 5) an annual production of about $500 \mathrm{t} / \mathrm{y}$ of PHB has been considered (necessary to estimate the hourly air emission rates); 6) 100\% pure PHB production; 7) DMC has been classified as a Class V of Annex I to Part Five of Italian Legislative Decree 152/2006 (Italian Parliament, 2006) following affinity rule (see explanation in section 2.4.4.); 8) DMC and 1,2-dichloroethene air emissions are below the materiality threshold (4000 g/h and $25 \mathrm{~g} / \mathrm{h}$, respectively); 8) $\mathrm{NO}_{\mathrm{x}}$ emission factor for catalytic oxidizer has been considered equal to those occurring in thermal treatment processes of biodegradable waste; 9) emission factors for hazardous waste have been used to estimate the emission due to the catalytic oxidizer applied to extraction process through 1,2dichloroethene; 10) the solid waste resulting from the DMC extraction is treated in a waste-toenergy plant for non-hazardous waste (see explanation in section 2.4.5.).

$<$ Table 2>

\subsubsection{Data collection and elaboration}

Primary data have been used for the processes taking place in laboratory, databases have been used for background processes, and estimates have been used for emissions or processes not taking place in the current plant, such as catalytic scrubbing. LCA was conducted utilizing GaBi 6 software. The databases used for obtaining background data were Gabi Professional Database (Thinkstep, 2015) and ecoinvent Version 2 database (Frischknecht et al., 2005). All main background processes used in this study are shown in Table 3. Detailed Life Cycle Inventories of the five scenarios are presented in Annexes A-E. 
With regards to life cycle impact assessment (LCIA), the following impact categories have been included: climate change (GWP), ozone depletion (OD), human toxicity cancer (HTc) and noncancer (HTnc), freshwater ecotoxicity (FE), acidification (AC), photochemical ozone formation (POF), freshwater eutrophication (EuF), marine eutrophication (EuM), terrestrial eutrophication (EuT), particulate matter formation (PM), ionizing radiation (IR), resource depletion (RD) and water depletion (WD). The methods recommended in the ILCD Handbook (EC-JRC, 2011, 2012) have been applied.

$<$ Table 3>

\subsubsection{Dimethyl carbonate toxicity and ecotoxicity characterization}

Since DMC characterization factors (CFs) of human toxicity and freshwater aquatic ecosystem toxicity were not available, they have been calculated following the approach proposed in the scientific consensus model USEtox (www.usetox.org) that is endorsed by the UNEP/SETAC Life Cycle Initiative and recommended by the ILCD Handbook for characterizing human toxicity and ecotoxicity in LCA (Westh et al., 2015). The CF calculation requires several types of input data: physicochemical substance properties, bioconcentration data and toxicological and ecotoxicological information (Fantke et al., 2017). Physicochemical and bioconcentration data of DMC were mainly derived from EPI Suite ${ }^{T M}$ (US EPA, 2016), while (eco)toxicological data were derived from ECHA's database on registered substances (European Chemicals Agency, 2017). Ecotoxicological and toxicological data used in this study are reported in Table 4. Regarding human toxicity, the $\mathrm{ED}_{50}$ values have been extrapolated from NOEC or NOEL based on a generic conversion factor of 9 (Huijbregts et al., 2005). Since experimental data are from subchronic and acute tests, a subchronic-to-chronic extrapolation factor of 2 and an acute-tochronic extrapolation factor of 5 have been used to extrapolate to chronic $\mathrm{ED}_{50}$ (Fantke et al., 2017). For ecotoxicity, chronic $E_{50}$ values have been calculated from NOEC using the extrapolation factors suggested by Payet (2004) and, when necessary, applying a generic chronic-to-acute ratio of 2 (Müller et al., 2017). All newly developed input data used in the USEtox model are reported in Table 5.

$<$ Table 4>

$<$ Table 5>

\subsubsection{Characterization of solid waste from extraction processes}

At first, elemental analysis was carried out on a $\mathrm{C}, \mathrm{H}$, and $\mathrm{N}$ Elemental Analyser. Next, organic compounds measurements were performed by gas chromatography coupled to mass spectrometry (GC/MS): the concentrations of dimethyl carbonate and 42 hazardous compounds (toxic, carcinogenic, mutagenic, flammable, etc.) were determined (see Annex F). Then, a 
colorimetric method was applied for the determination of aldehyde concentrations (expressed as formaldehyde). Afterward, 19 metals (Be, Al, V, Cr, Mn, Fe, Co, Ni, Cu, Zu, As, Ag, Cd, Sb, $\mathrm{Ba}, \mathrm{TI}, \mathrm{Pb}, \mathrm{Hg}, \mathrm{Sn}$ ) were evaluated by inductively coupled plasma mass spectrometry (ICP-MS). Finally, ion chromatography was applied for determination of chlorine content (fundamental test in solid biomass for power sector). As last step, Mahler bomb calorimeter was used for determining higher heating value $(\mathrm{HHV})$ of the solid waste and subsequently its lower heating value (LHV).

\section{Results and discussion}

The first part of the study results describes the outcome of analyses performed and models applied to obtain all data necessary to carry out the LCA. The second part of the study results reports the evaluation by means of LCA.

\subsection{Toxicity for DMC and solid waste}

Using the extraction process through halogenated hydrocarbons presents a considerable disadvantage, namely the use of highly toxic solvents. It is noteworthy that IARC has classified dichloromethane as probable carcinogen to humans (Group 2A) and 1,2-dichloroethane and chloroform as possibly carcinogens (Group 2B). On the contrary, dimethyl carbonate - according to ACGIH, IARC, NTP - has not been classified as carcinogen. Consequently, it is fundamental that the comparison between DMC-based protocol and the extraction through halogenated hydrocarbons considers also the (eco)toxicity effects of the extraction solvents. Results of human toxicity and freshwater aquatic ecotoxicity characterization of DMC calculated with USEtox are reported in Table 6. The corresponding characterization factors of 1,2dichloroethane are shown in the same table and are up to 2 orders of magnitude higher than for DMC. Dichloromethane or chloroform, both used in extraction processes of PHB, show characterization results very similar to 1,2-dichloroethane. As it is possible to observe, the toxicity CFs of DMC are comparatively low ranging from $2.5 \times 10^{-10}$ to $2.7 \times 10^{-6}$ cases $/ \mathrm{kg}$ emitted and from $6.7 \times 10^{-10}$ to $7.4 \times 10^{-6} \mathrm{DALY} / \mathrm{kg}$ emitted, respectively, for different emission compartments. Also the freshwater aquatic ecotoxicity CFs are low ranging from 0.2 to 6.7 $\mathrm{PDF} \cdot \mathrm{m}^{3} \cdot \mathrm{day} / \mathrm{kg}$ emitted. As for ecotoxicity, it is noteworthy that freshwater aquatic ecotoxicity CFs have been obtained by so-called 'limit tests'. A 'limit test' is an acute toxicity test in which, if no ill-effects occur at a pre-selected maximum dose, no further testing at greater exposure levels is required (Duffus, 2009). Therefore, a conservative approach has been applied considering no observed effect concentrations (NOEC) to extrapolate to concentrations resulting in $50 \%$ effect in the exposed freshwater ecosystem species $\left(E_{50}\right)$.

As additional comparison to give an impression of the order of magnitude of presented CFs, the human toxicity CF of formaldehyde (carcinogen to humans Group 1) for the emission to 
household indoor air is $4.55 \times 10^{-3}$ cases $/ \mathrm{kg}$ emitted, while the corresponding CF of DMC is $2.72 \times 10^{-6}$ cases $/ \mathrm{kg}$ emitted and the aquatic ecotoxicity CF of DDT (persistent organic pollutant, worldwide banned) for the emission to continental freshwater is $2.78 \times 10^{5} \mathrm{PAF} \cdot \mathrm{m}^{3} \cdot \mathrm{day} / \mathrm{kg}$ emitted, while the corresponding CF of DMC is $10.8 \mathrm{PAF} \cdot \mathrm{m}^{3} \cdot \mathrm{day} / \mathrm{kg}$ emitted. These findings and considerations agree with a number of authors that referred to DMC as a substance benign to human health (Lissel et al., 1989; Ono, 1997; Tundo and Selva, 2002) and eco-friendly (Tundo et al., 2000; Vasapollo et al., 2003; Miao et al., 2008).

While EU legislations concerning air quality is rather homogeneous, based on the setting of limits for the concentration of certain pollutants into the air, the EU rules regarding industrial emissions into the atmosphere is more heterogeneous. In Italy this issue is regulated by the Legislative Decree 152/2006 (Italian Parliament, 2006). National emission limits have been set by the Decree for different substances based on their hazard properties. The Decree organizes the organic substances in five classes in order of decreasing toxicity. Not all organic substances are listed, but it is possible to define the class of a substances referring to substances occurring in the list and with similar toxic properties ('affinity rule'). Dimethyl carbonate is not listed by the Decree but through the 'affinity rule' it can be classified in Class V. For this class, the emission limit is set to $600 \mathrm{mg} / \mathrm{Nm}^{3}$ that corresponds to $4000 \mathrm{~g} / \mathrm{h}$. These values have been used for LCA modelling.

The solid waste resulting from PHB extraction process was analysed to attempt a first classification of it as 'hazardous' or 'not hazardous' waste. These analyses were necessary to hypothesize its end-of-life. In fact, all 'hazardous' waste must be disposed in accordance with regulations more stringent than for 'not hazardous' waste. Main results of chemical analyses carried out on solid waste coming from the extraction process of PHB from microbial cells are presented in Table 7. All hazardous organic compounds show results lower than the detection limits (data not reported). According to these results and in first approximation, it is possible to categorize this waste as 'not hazardous'. The content lower than $1 \%$ of halogenated organic substances, expressed as chlorine, suggests that the waste could be sent to incineration plants respecting the restriction that the gas resulting from the incineration is raised to a temperature of at least $850^{\circ} \mathrm{C}$ for at least two seconds (as established by Directive 2010/75/EU, European Commission, 2010). The incineration way is reinforced by the low heating value (LHV) of the waste $(14,400 \mathrm{~J} / \mathrm{g})$ that is well comparable with other waste usually sent to waste-to-energy plants, like textile $(11,789 \mathrm{~J} / \mathrm{g}$ ), leather and rubber $(14,265 \mathrm{~J} / \mathrm{g}$ ), and wood $(9,310 \mathrm{~J} / \mathrm{g}$ ) (World Bank, 1999). Another interesting end-of-life option for the extraction waste could be the composting, suggested by the high carbon content (47.6\%) and the low concentration of metals considered hazardous for such employment (Legislative Decrees, 217/06, Italian Parliament, 2006; and D.G.R. 1528/2006, Regional Council of Abruzzo Region, 2006). Composting of biomass remaining after PHB recovery was a solution proposed also by Nonato et al. (2001). 
<Table 6>

$<$ Table 7>

\subsection{Overall environmental performance results}

Environmental performance results of PHB production processes based on DMC protocol considering two alternative ways of extraction (from microbial slurry or from dried biomass) and taking into account two different ways of polymer recovery (solvent evaporation or polymer precipitation) are reported in Table 8 . The four scenarios are compared to the reference scenario 'DCE' (extraction with 1,2-dichloroethane). The relative contributions to each impact category from the main steps involved within each scenarios are illustrated in Fig. 2 to 4 . Each PHB production process is subdivided into six steps: 1) biomass preparation (which includes drying in scenarios 'Dry-Evap' and 'Dry-precip'), 2) chemicals production, 3) PHB extraction, 4) chemicals recovery, 5) catalytic oxidation for air emission abatement, 6) solid waste treatment.

$<$ Figure 2>

$<$ Figure 3>

$<$ Figure 4>

Table 8 shows that all four scenarios using DMC show better environmental performances than the process employing 1,2-dichloroethane for all considered impact categories. GHG emissions due to 'DCE scenario' are about 5 to 15 times higher than scenarios representing the extraction via DMC. Acidification, ozone formation precursors, marine and terrestrial eutrophication, particulate matter formation and water depletion due to process by DCE are about 4 to 20 times higher than those of the DMC protocol. The difference between 'DCE' and 'DMC' scenarios for resources depletion shows 40 times difference. The emissions of (eco)toxic substances of 'DCE scenario' are up to 2 orders of magnitude higher than the other scenarios. Finally, ionizing radiation, ozone-depletion gas emissions and freshwater eutrophication related to process through DCE is up to 350 times higher than 'DMC scenarios'. Note that the biggest differences are always between 'DCE' and 'Dry-Evap' scenarios.

When comparing the four scenarios related to DMC protocol, we observe that extraction applied to dry biomass is always preferable to the one from slurry, and that recovery by solvent evaporation is always preferable to polymer precipitation with EtOH. Therefore, the scenario which evaluates extraction of the biopolymer from dried biomass and recovery by precipitation (Dry-Evap scenario) seems to be the most promising, in spite of the fact that recovery obtained through extraction from dried biomass is lower (92\%) than obtained with the extraction from slurry $(96 \%)$. Such a result is dependent on three main factors: 1$)$ the moderate solubilization, 
and consequent loss, of DMC in the slurry; 2) the high energy requirement of pervaporation systems (in the scenarios "Precip"); 3 ) the adding of $\mathrm{EtOH}$ which increases the mass that has to be dried (in the scenarios "Precip").

For the contribution analysis, the impact categories have been arranged in two groups. The first group includes GWP, AC, EuT, EuM, POF, PM, HTnc, RD and WD. The second group comprises EuF, FE, HTc, IR, and OD. As we observe from Fig. 2 and 3, the first group shows several dominant processes for each impact category. Frequently, PHB extraction is a dominant process for 'evaporation' scenarios (scenarios 1 and 2); chemicals production and recovery (sometimes also catalytic oxidation) are the dominant processes in 'precipitation' scenarios (3 and 4); chemicals production is dominant in 'slurry' scenarios (1 and 3 ); and biomass preparation is dominant in 'dry' scenarios (2 and 4). The distinct dominating factors provide a quite differentiated picture in the contribution analysis. 'Slurry-evap' is dominated by chemicals production and PHB extraction; in 'Dry-evap', biomass preparation and PHB extraction play the main role; 'Slurry-precip' shows chemicals production, chemicals recovery and catalytic oxidation as the main processes (the last one is important only in POF); 'Dry-precip' is dominated by biomass preparation, chemicals production, chemicals recovery, and catalytic oxidation (the last one is important only in POF). As indicated by Fig. 4, the second group is entirely dominated by the chemical production in all four scenarios.

From these results, we identified three main processes: chemical production, PHB extraction and chemicals recovery. In particular, the most important contributor to chemicals production processes is DMC that is used in abundant amount especially in scenarios 'Slurry-evap' and 'Slurry-precip' (see Annexes A and C). As shown, DMC consumption can be strongly reduced using dry-biomass instead of microbial slurry. Concluding, a reduction in DMC consumption and an increase of its recovery rate should therefore be among the major goals in the future scaleup and optimization of DMC based processes.

Regarding PHB extraction and chemicals recovery, these processes are dominated, respectively, by DMC evaporation through air dryers (see Annexes $\mathrm{A}$ and $\mathrm{B}$ ) and pervaporation (see Annexes $C$ and $D$ ), both high energy-requiring processes. It is possible that a recovery of heat from material flows to be cooled by means of a heat exchanger would lead to a significant thermal energy saving. Lastly, in order to reduce the energy consumption due to the DMC recovery, an alternative to pervaporation could be analysed. All these recommendations should be considered for the scaling up of the processes to industrial-scale. It should be in fact reminded that the preliminary scale-up carried out in current study was only oriented to the comparison of the basic information available for alternative process schemes: the process optimization to be carried out during a more detailed scale-up is actually expected to further increase the performances of the industrial process (Sinnott, 1993; Bisio and Kabel, 1985).

From the point of view of the role of DMC in the environmental sustainability of the process, it is important to highlight that the chemical pathway of DMC production (in this case-study via the 
oxidative carbonylation process; Righi et al., 2016) plays a fundamental role for the obtained results: the 'greener' the solvent, the less environmentally impacting the extraction.

To compare the results of our study to those of other scientific works is challenging. One reason is that to the best of our knowledge no LCA studies focusing only on PHAs extraction phase have been published. Moreover, although several scientific studies have been published about LCA method applied to PHAs production, they are usually not comparable. Among them, three reviews (Hottle et al., 2013; Yates and Barlow, 2013; Narodoslawsky et al., 2015) analyse and compare the results obtained by a total of fifteen studies. All studies report the global warming potential (GWP), while only a limited number of studies has also evaluated other environmental impacts (Harding et al., 2007; Khoo et al., 2010; Kendall, 2012). Global warming potential ranges from $-4 \mathrm{~kg} \mathrm{CO}$ eq. (Kurdikar et al., 2000) to $11.9 \mathrm{~kg} \mathrm{CO}$ eq. (Kendall, 2012) based on different system boundaries, feedstock, source of energy, etc. Completely different is the value reported by Rostkowski et al. (2012) with $942 \mathrm{~kg} \mathrm{CO}$ eq, mainly due to biopolymer recovery. The values of GWP provided by the present study (3.9-11 $\left.\mathrm{kg} \mathrm{CO}_{2} \mathrm{eq}\right)$ lie within the range of values reported in other studies. Since our values refer only to polymer extraction, our results would agree to the above range only if the PHAs extraction were one of the main contributors to the total impact. This hypothesis agrees to previous scientific works who observed that recovery is the dominant process (Rostkowski et al., 2012) or one of the dominant processes (Kendall et al., 2012; Fernández-Dacosta et al. 2015) contributing to the total environmental impacts of PHB production.

$<$ Table 8>

\section{Conclusions}

LCA was applied to a novel procedure based on DMC for the extraction of PHB from bacterial biomass. Extraction of the polymer from microbial slurry or from dried biomass and recovery by solvent evaporation or polymer precipitation were assessed, obtaining four different scenarios. LCA results demonstrate that the environmental performances of DMC protocol are far better than those of the most common processes using halogenated hydrocarbons. Among the four scenarios tested the one that evaluates extraction from dried biomass and PHB recovery by precipitation is always the most promising. These findings encourage the research towards the application on pilot scale of DMC with the aim to verify the first results and to study its possible economic and technical implications at the industrial production scale. The main recommendations for the scaling up drawn from this study are: i) to prefer processes using dry biomass instead of concentrated microbial slurries since in the latter the loss of DMC is higher; 2) to enhance the efficiency of polymer recovery and the DMC recovery efficiency after the polymer extraction in order to reduce the DMC consumption; 3 ) to consider a heat exchanger 
for thermal energy saving, and 4) to consider an alternative to the pervaporation for chemicals recovering since this technology is very energy-requiring.

\section{Acknowledgments}

We gratefully acknowledge the financial support from Emilia Romagna Region (project "CIRI Energia e Ambiente POR-FESR Addendum RA"), UE H2020 EIT KIC CLIMATE (project "BioGrapPa"), and in part from the Marie Curie project Quan-Tox (grant agreement no. 631910) funded by the European Commission under the Seventh Framework Programme. In addition, we wish to thank the following persons who made valuable suggestions or who have otherwise provided input to the work that lead to the manuscript: Federica Abbondanzi, Laura Billi, Lorenza Gabrielli, Monica Miraglia, Andrea Pasteris, Beatrice Salieri, and Rosita Setti.

\section{References}

Anjum, A., Zuber, M., Zia, K.M., Noreen, A., Anjum, M.N., Tabasum, S., 2016. Microbial production of polyhydroxyalkanoates (PHAs) and its copolymers: A review of recent advancements. Int. J. Biol. Macromol. 89, 161-174.

Baker, C.G.J., McKenzie, K.A., 2005. Energy consumption of industrial spray dryers. Drying Technol. 23, 365-386.

Bisio, A., Kabel, R.L., 1985. Scale-up of chemical processes: conversion from laboratory scale tests to successful commercial size design, Wiley, New York.

Delledonne, D., Rivetti, F., Romano, U., 2001. Developments in the production and application of dimethylcarbonate. Appl. Catal. A-Gen. 221, 241-251.

Dietrich, K., Dumont, M.J., Del Rio, L.F., Orsat, V., 2017. Producing PHAs in the bioeconomyTowards a sustainable bioplastic. Sustain. Prod. Consumpt. 9, 58-70.

Duffus, J., 2009. Glossary for chemists of terms used in toxicology (IUPAC Recommendations 1993). Pure Appl. Chem. 65, 2003-2122.

EC-JRC, 2011. International Reference Life Cycle Data System (ILCD) Handbook Recommendations for Life Cycle Impact Assessment in the European Context, first ed. European Commission Available at: http://eplca.jrc.ec.europa.eu/ (visited on February 2017) EC-JRC, 2012. Characterisation Factors of the ILCD Recommended Life Cycle Impact Assessment Methods. Database and Supporting Information, first ed. European Commission, Joint Research Centre, Institute for Environment and Sustainability.

EEA, 2013. EMEP/EEA air pollutant emission inventory guidebook 2013. Technical guidance to prepare national emission inventories. EEA Technical report 12. 
European Bioplastic, 2015. Bioplastics facts and figures. Available at:

http://www.corbion.com/media/203221/eubp factsfigures bioplastics 2013.pdf (visited on February 2017)

European Chemicals Agency, 2017. Dimethyl carbonate. Available at:

https://echa.europa.eu/it/registration-dossier/-/registered-dossier/14944/ (visited on February 2017)

European Commission, 2010. Directive 2010/75/EU of the European Parliament and of the Council of 24 November 2010 on industrial emissions (integrated pollution prevention and control). Official Journal of the European Union L334, 17.12.2010.

Fantke, P. (Ed.), Huijbregts, M., van de Meent, D., Margni, M., Jolliet, O., Rosenbaum, R.K., McKone, T.E., Hauschild, M., 2017. USEtox® 2.0 Manual: Organic Substances (Version 2). Fernández-Dacosta, C., Posada, J.A., Kleerebezem, R., Cuellar, M.C., Ramirez, A., 2015. Microbial community-based polyhydroxyalkanoates (PHAs) production from wastewater: Techno-economic analysis and ex-ante environmental assessment. Bioresource Technol. 185, 368-377.

Frischknecht, R., Jungbluth, N., Althaus, H.J., Doka, G., Dones, R., Heck, T., Hellweg, S., Hischier, R., Nemecek, T., Rebitzer, G., Spielmann, M., 2005. The ecoinvent database: Overview and methodological framework, Int. J. Life Cycle Assess. 10, 3-9. Hao, J., Wang, X., Wang, H., 2017. Investigation of polyhydroxyalkanoates (PHAs) biosynthesis from mixed culture enriched by valerate-dominant hydrolysate. Front. Environ. Sci. Eng. 11, 516.

Harding, K.G., Dennis, J.S., von Blottnitz, H., Harrison, S.T.L., 2007. Environmental analysis of plastic production processes: Comparing petroleum-based polypropylene and polyethylene with biologically-based poly- $\beta$-hydroxybutyric acid using life cycle analysis. J. Biotechnol. 130, 57-66. Heimersson, S., Morgan-Sagastume, F., Peters, G.M., Werker, A., Svanström, M., 2014. Methodological issues in life cycle assessment of mixed-culture polyhydroxyalkanoate production utilising waste as feedstock. New Biotechnol. 31, 383-393.

Hischier, R., Hellweg, S., Capello, C., Primas, A., 2005. Establishing life cycle inventories of chemicals based on differing data availability. Int. J. LCA. 10, 59-67.

Hottle, T.A., Bilec, M.M., Landis, A.E., 2013. Sustainability assessments of bio-based polymers. Polym. Degrad. Stab. 98, 1898-1097.

Huijbregts, M.A.J., Rombouts, L.J.A., Ragas, A.M.J., van de Meent, D., 2005. Humantoxicological effect and damage factors of carcinogenic and noncarcinogenic chemicals for life cycle impact assessment. Integr. Environ. Assess. Manag. 1, 181-244. Italian Parliament, 2006. Legislative Decree $29^{\text {th }}$ April $2006 \mathrm{~N}^{\circ} 217$. [in Italian] Italian Parliament, 2006. Legislative Decree $3^{\text {rd }}$ April $2006 \mathrm{~N}^{\circ}$ 152. [in Italian] Kendall, A., 2012. A life cycle assessment of biopolymer production from material recovery facility residuals. Resour. Conserv. Recy. 61, 69-74. 
Keshavarz, T., Roy, I., 2010. Polyhydroxyalkanoates: Bioplastics with a green agenda. Curr. Opin. Microbiol. 13, 321-326.

Khoo, H.H., Tan, R.B.H., Chng, K.W.L., 2010. Environmental impacts of conventional plastic and bio-based carrier bags_-part 1: life cycle production. Int. J. Life Cycle Assess. 15, 284-293. Kujawski, W., 2000. Application of Pervaporation and Vapor Permeation in Environmental Protection. Polish Journal of Environmental Studies. 9, 13-26.

Kurdikar, D., Fournet, L., Slater, S.C., Paster, M., Gruys, K.J., Gerngross TU, Coulon, R., 2000. Greenhousegas profile of a plastic material derived from a genetically modified plant. J. Ind. Ecol. 4, 107-122.

Lissel, M., Rohani-Dezfuli, A.R., Vogt, G., 1989. Reactions with dimethyl carbonate. Part 3. applications and mechanism of monomethylation or bis-methylation of aromatic-amines with dimethyl carbonate J. Chem. Res. 10, 2434-2452.

Miao, X., Fischmeister, C., Bruneau, C., Dixneuf, P.H., 2008. Dimethyl carbonate: an ecofriendly solvent in ruthenium-catalyzed olefin metathesis transformations. ChemSusChem. 1, 813-816.

Montiel-Jarillo, G., Carrera, J., Suárez-Ojeda, M.E., 2017. Enrichment of a mixed microbial culture for polyhydroxyalkanoates production: Effect of $\mathrm{pH}$ and $\mathrm{N}$ and $\mathrm{P}$ concentrations. Sci. Total Environ. 583, 300-307.

Morfino, A., 2009. Collection, production and analysis of the inventory data of the life cycle of

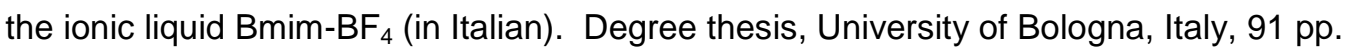

Müller, N., de Zwart, D., Hauschild, M., Kijko, G., Fantke, P., 2017. Exploring REACH as potential data source for characterizing ecotoxicity in life cycle assessment. Environ. Toxicol. Chem. 36, 492-500.

Narodoslawsky, M., Shazad, K., Kollmann, R., Schnitzer, H., 2015. LCA of PHA Production Identifying the Ecological Potential of Bio-plastic. Chem. Biochem. Eng. Q., 29, 299-305.

Neel, J., 1991. Introduction to pervaporation. Pervaporation membrane separation processes, Elsevier, Amsterdam.

Nonato, R.V., Mantelatto, P.E., Rossell, C.E.V., 2001. Integrated production of biodegradable plastic, sugar and ethanol. Appl. Microbiol. Biot. 57, 1-5.

Ojeda, T., 2013. Polymers and the Environment, in: Yılmaz, F (Ed.), Polymer Science, InTech. Ono, Y., 1997. Dimethyl carbonate for environmentally benign reactions. Catalysis Today 35, 15-25.

Patel, M., Bastioli, C., Marini, L., Würdinger, E., 2005. Life cycle assessment of biobased polymers and natural fibres composites. Biopolym. Online 10.

Payet, J., 2004. Assessing toxic impacts on aquatic ecosystems in life cycle assessment (LCA). Doctoral thesis, Ecóle Polytechnique Fédérale de Lausanne, Lausanne, Switzerland, 232 pp.

Perry, R.H., Green, D.W., Maloney, J.O., 1984. Perry's Chemical Engineers'Handbook, 6th ed. McGraw-Hill, New-York. 
Regional Council of Abruzzo Region, 2006. D.G.R. 1528 27.12.2006. [in Italian]

Righi, S., Bandini, V., Fabbri, D., Cordella, M., Tugnoli, A., Stramigioli, C., 2016. Modelling of an alternative process technology for biofuel production and assessment of its environmental impacts. J. Cleaner Prod. 122, 42-51.

Righi, S., Morfino, A., Galletti, P., Samorì, C., Tugnoli, A., Stramigioli, C., 2011. Comparative cradle-to-gate life cycle assessments of cellulose dissolution with 1-butyl-3-methylimidazolium chloride and N-methyl-morpholine-N-oxide. Green Chem.13, 367-375.

Rostkowski, K.H., Criddle, C.S., Lepech, M.D., 2012. Cradle-to-Gate Life Cycle Assessment for a Cradle-to-Cradle Cycle: Biogas-to-Bioplastic (and Back). Environ. Sci. Technol. 46, 98229829.

Samorì, C., Basaglia, M., Casella, S., Favaro, L., Galletti, P., Giorgini, L., Marchi, D., Mazzocchetti, L., Torri, C., Tagliavini, E., 2015. Dimethyl carbonate and switchable anionic surfactants: two effective tools for the extraction of polyhydroxyalkanoates from microbial biomass. Green Chem. 17, 1047-1056.

Senior, P.J., Wright, L.F., Alderson, B., 1982. Extraction Process. U.S. Patent 4324907.

Sinnott, R.K., 1993. Coulson and Richardson's Chemical Engineering, Volume 6, Pergamon, Oxford.

Steinbüchel, A., Lutke-Eversloh, T., 2003. Metabolic engineering and pathway construction for biotechnological production of relevant polyhydroxyalkanoates in microorganisms. Biochem. Eng. J. 16, 81-96.

Tabone, M.D., Cregg, J.J., Beckman, E.J., Landis, A.E., 2010. Sustainability metrics: life cycle assessment and green design in polymers. Environ. Sci. Technol. 44, 8264-8269.

Thinkstep, 2015. Available at: http://www.gabi-software.com/databases/gabidatabases/professional/ (visited on February 2017)

Tundo, P., Anastas, P., Black, D.St.C., Breen, J., Collins, T., Memoli, S., Miyamoto, J., Polyakoff, M., Tumas, W., 2000. Synthetic pathways and processes in green chemistry. Introductory overview. Pure Appl. Chem. 72, 1207-1228.

Tundo, P., Selva, M., 2002. The Chemistry of Dimethyl Carbonate. Acc. Chem. Res. 35, 706716.

US EPA, 2016. Estimation Programs Interface Suite ${ }^{\mathrm{TM}}$ for Microsoft ${ }^{\circledR}$ Windows, $v$ 4.11. United States Environmental Protection Agency, Washington, DC, USA.

Van Wegen, R.J., Ling, Y., Middelberg, A.P.J., 1998. Industrial production of polyhydroxyalkanoates using Escherichia coli: an economic analysis. Chem. Eng. Res. Des. 76, 417-426.

Vasapollo, G., Mele, G., Maffei, A., Del Sole, R., 2003. Palladium-catalysed cyclocarbonylation reactions in dimethyl carbonate, an eco-friendly solvent and ring-opening reagent. Appl. Organomet. Chem. 17, 835-839. 
Vega-Castro, O., Contreras-Calderon, J., León, E., Segura, A., Arias, M., 2016. Characterization of a polyhydroxyalkanoate obtained from pineapple peel waste using Ralsthonia eutropha. J. Biotechnol. 231, 232-238.

Westh, T.B., Hauschild, M.Z., Birkved, M., Jørgensen, M.S., Rosenbaum, R.K., Fantke, P., 2015. The USEtox story: A survey of model developer visions and user requirements. Int. J. Life Cycle Assess. 20, 299-310.

World Bank, 1999. Municipal Solid Waste Incineration. Technical Guidance Report. Washington, DC, USA.

Yates, M.R., Barlow, C.Y., 2013. Life cycle assessments of biodegradable, commercial biopolymers - A critical review. Resour. Conserv. Recy. 78, 54-66.

Zlokarnik, M., 2002. Scale-up in chemical engineering, Wiley, Weinheim. 
Table 1 Main parameters and data sources used to model the extraction processes.

\begin{tabular}{|l|l|l|}
\hline Equipment & Data & Data sources \\
\hline \multirow{3}{*}{ Centrifuges } & Specific power & Perry et al., 1984 \\
\cline { 2 - 3 } & Volumetric capacity & Perry et al., 1984 \\
\cline { 2 - 3 } & Operating time & Harding et al., 2007 \\
\hline Batch reaction vessels & Specific power & Morfino, 2009 \\
\hline & Volume & Morfino, 2009 \\
\hline Air dryers & Energy consumption & Baker and McKenzie, 2005 \\
\hline & Purge flow & Aspen HYSYS® \\
\hline & Heat loss & Aspen HYSYS® \\
\hline Catalytic oxidizer & Emission factors & EEA, 2013 \\
\hline Pervaporation systems & General information & Kujawski et al, 2000 \\
\hline & General information & Neel, 1991 \\
\hline
\end{tabular}


Table 2 Main features of the five scenarios analysed in our study.

\begin{tabular}{|l|l|c|c|}
\hline Code & Solvent & Biomass state & Separation \\
\hline 1 Slurry-Evap & DMC & microbial slurry & DMC evaporation \\
\hline 2 Dry-Evap & DMC & dry biomass & DMC evaporation \\
\hline 3 Slurry-Precip & DMC & microbial slurry & precipitation with $\mathrm{EtOH}$ \\
\hline 4 Dry-Precip & DMC & dry biomass & precipitation with $\mathrm{EtOH}$ \\
\hline 5 DCE & 1,2 -dichloroethane & dry biomass & Precipitation with $\mathrm{MeOH} /$ water \\
\hline
\end{tabular}


Table 3 Main background processes used in this study.

\begin{tabular}{|c|c|c|}
\hline Process name & Data source & Geographic location \\
\hline Electricity grid mix & PE International ${ }^{\S}$ & IT \\
\hline Process steam from natural gas $95 \%$ & PE International $\left.\right|^{\S}$ & IT \\
\hline Ethylene dichloride, at plant & Ecoinvent & RER \\
\hline Ethanol from ethylene, at plant & Ecoinvent & RER \\
\hline Methanol, at plant & Ecoinvent & GLO \\
\hline Water (desalinated, deionized) & PE International ${ }^{\$}$ & $\mathrm{DE}$ \\
\hline Dimethyl carbonate, at plant & Righi et al, 2016 & $\mathrm{DE}$ \\
\hline $\begin{array}{l}\text { Truck, Euro 0-6 mix, } 20-26 \text { t gross } \\
\text { weight / } 17.3 \text { t payload capacity }\end{array}$ & PE International ${ }^{\S}$ & GLO \\
\hline Diesel production mix, at refinery & PE International $\left.\right|^{\S}$ & EU-27 \\
\hline $\begin{array}{l}\text { Waste incineration of biodegradable } \\
\text { waste fraction in municipal solid waste } \\
\text { (MSW), ELCD/CEWEP }\end{array}$ & PE International $\left.\right|^{\S}$ & EU-27 \\
\hline
\end{tabular}

${ }^{\S} \mathrm{PE}$ International is now Thinkstep 
Table 4 Toxicological and ecotoxicological data of DMC used to calculate characterization factors for human toxicity and freshwater aquatic ecosystem toxicity. All data are from the ECHA registered substances database (European Chemicals Agency, 2017).

\begin{tabular}{|c|c|c|c|c|c|}
\hline \multicolumn{6}{|c|}{ TOXICOLOGICAL DATA } \\
\hline Route & Animal & Test type & End-point & Value & Chronic ED 50 \\
\hline Inhalation & Rat & Acute & NOEC & $>5.36 \mathrm{mg} / \mathrm{L}$ & $9.65 \mathrm{mg} / \mathrm{L}$ \\
\hline Ingestion & Rat & Subchronic & NOEL & $>500 \mathrm{mg} / \mathrm{kg} \mathrm{bw} / \mathrm{day}$ & $2250 \mathrm{mg} / \mathrm{kg} \mathrm{bw} / \mathrm{day}$ \\
\hline \multicolumn{6}{|c|}{ ECOTOXICOLOGICAL DATA } \\
\hline Trophic level & Specie & Test type & End-point & Value & Chronic $\mathrm{EC}_{50}$ \\
\hline Fish & Danio rerio & ST (96 h) & NOEC & $100 \mathrm{mg} / \mathrm{L}$ & $165 \mathrm{mg} / \mathrm{L}$ \\
\hline Invertebrates & Daphnia magna & LT $(21 d)$ & NOEC & $25 \mathrm{mg} / \mathrm{L}$ & $120 \mathrm{mg} / \mathrm{L}$ \\
\hline Algae & Selenastrum capricornutum & $\mathrm{LT}(72 \mathrm{~h})$ & NOEC & $100 \mathrm{mg} / \mathrm{L}$ & $480 \mathrm{mg} / \mathrm{L}$ \\
\hline
\end{tabular}


Table 5 DMC data used in the USEtox model, version 2.02.

\begin{tabular}{|c|c|c|c|}
\hline PARAMETERS & Unit & Value & References [notes] \\
\hline CAS number & - & $616-38-6$ & - \\
\hline \multicolumn{4}{|l|}{ Physical and chemical data } \\
\hline Molar mass & $\mathrm{g} / \mathrm{mol}$ & $9.010^{\top}$ & - \\
\hline pKa chemical class & - & Neutral & - \\
\hline $\begin{array}{l}\text { Partitioning coefficient } \\
\text { between n-octanol and } \\
\text { water }\end{array}$ & $\mathrm{L} / \mathrm{L}$ & 1.7 & US EPA, 2016 [EPI Suite ${ }^{T M}$ ] \\
\hline $\begin{array}{l}\text { Partitioning coefficient } \\
\text { between organic carbon } \\
\text { and water }\end{array}$ & $\mathrm{L} / \mathrm{kg}$ & 2.9 & US EPA, 2016 [EPI Suite ${ }^{\mathrm{TM}}$ ] \\
\hline $\begin{array}{l}\text { Henry's law constant (at } \\
25^{\circ} \mathrm{C} \text { ) }\end{array}$ & $\mathrm{Pa} \cdot \mathrm{m}^{3} / \mathrm{mol}$ & 8.7 & US EPA, 2016 [EPI Suite ${ }^{\mathrm{TM}}$ ] \\
\hline Vapor pressure (at $25^{\circ} \mathrm{C}$ ) & $\mathrm{Pa}$ & $7.610^{3}$ & European Chemicals Agency, 2017 \\
\hline Solubility (at $\left.25^{\circ} \mathrm{C}\right)$ & $\mathrm{mg} / \mathrm{L}$ & $1.1510^{5}$ & European Chemicals Agency, 2017 \\
\hline \multicolumn{4}{|c|}{ Rate constant degradation and bioaccumulation } \\
\hline $\begin{array}{l}\text { Rate constant } \\
\text { degradation in air }\end{array}$ & $1 / \mathrm{s}$ & $2.310^{-7}$ & Based on US EPA, 2016 [EPI Suite ${ }^{\mathrm{TM}}$ ] \\
\hline $\begin{array}{l}\text { Rate constant } \\
\text { degradation in water }\end{array}$ & $1 / \mathrm{s}$ & $5.410^{-7}$ & Based on US EPA, 2016 [EPI Suite ${ }^{\mathrm{TM}}$ ] \\
\hline $\begin{array}{l}\text { Rate constant } \\
\text { degradation in sediment }\end{array}$ & $1 / \mathrm{s}$ & $2.710^{-7}$ & Based on US EPA, 2016 [EPI Suite ${ }^{\mathrm{TM}}$ ] \\
\hline $\begin{array}{l}\text { Rate constant } \\
\text { degradation in soil }\end{array}$ & $1 / \mathrm{s}$ & $5.910^{-8}$ & Based on US EPA, 2016 [EPI Suite ${ }^{\mathrm{TM}}$ ] \\
\hline $\begin{array}{l}\text { Bioaccumulation factor in } \\
\text { fish }\end{array}$ & $\mathrm{L} / \mathrm{kg}_{\text {fish }}$ & 3.2 & Based on US EPA, 2016 [EPI Suite ${ }^{\mathrm{TM}}$ ] \\
\hline \multicolumn{4}{|c|}{ Toxicological and ecotoxicological data } \\
\hline $\begin{array}{l}\text { Average of the log of the } \\
\text { species-specific } \\
\text { geometric means of } \\
\text { concentrations affecting } \\
50 \% \text { of the exposed } \\
\text { species population for a } \\
\text { defined endpoint }\end{array}$ & $\mathrm{mg} / \mathrm{L}$ & 2.3 & $\begin{array}{l}\text { Calculated [from ecotoxicological data, } \\
\text { Table 4] }\end{array}$ \\
\hline $\begin{array}{l}\text { Human-equivalent lifetime } \\
\text { dose per person that } \\
\text { causes a non-cancer } \\
\text { disease probability of } \\
50 \% \text { via inhalation }\end{array}$ & $\mathrm{kg} /$ lifetime & $7.810^{2}$ & $\begin{array}{c}\text { Calculated [from acute inhalation } \\
\text { LC50, Table 4] }\end{array}$ \\
\hline $\begin{array}{l}\text { Human-equivalent lifetime } \\
\text { dose per person that } \\
\text { causes a non-cancer } \\
\text { disease probability of } \\
50 \% \text { via ingestion }\end{array}$ & $\mathrm{kg} /$ lifetime & $9.810^{2}$ & $\begin{array}{c}\text { Calculated [from subchronic ingestion } \\
\text { NOEL, Table 4] }\end{array}$ \\
\hline
\end{tabular}


Table 6 Human toxicity and freshwater aquatic ecotoxicity characterization factors of dimethyl carbonate (DMC) and 1,2-dichloroethane (DCE).

\begin{tabular}{|c|c|c|c|c|}
\hline \multicolumn{5}{|c|}{ MIDPOINT LEVEL CHARACTERIZATION FACTORS } \\
\hline \multirow[t]{2}{*}{ Type of emission } & \multicolumn{2}{|c|}{$\begin{array}{c}\text { Human toxicity } \\
\text { [cases/kg emitted] }\end{array}$} & \multicolumn{2}{|c|}{$\begin{array}{l}\text { Freshwater aq. ecotoxicity } \\
\text { [PAF.m3.day/kg emitted] }\end{array}$} \\
\hline & DMC & DCE & DMC & DCE \\
\hline to household indoor air & $2.7210^{-6}$ & $6.0510^{-5}$ & $3.7910^{-1}$ & $1.2210^{-1}$ \\
\hline to industrial indoor air & $9.2410^{-8}$ & $2.1310^{-6}$ & $3.7910^{-1}$ & $1.2210^{-1}$ \\
\hline to urban air & $1.9410^{-8}$ & $5.1410^{-1}$ & $3.7910^{-1}$ & $1.2210^{-1}$ \\
\hline to continental rural air & $3.9310^{-9}$ & $1.7010^{-7}$ & $3.7910^{-1}$ & $1.2210^{-1}$ \\
\hline to continental freshwater & $8.8510^{-9}$ & $1.5710^{-6}$ & $1.3510^{1}$ & $1.5110^{1}$ \\
\hline to continental sea water & $2.4610^{-10}$ & $3.9810^{-8}$ & $2.2810^{-2}$ & $2.3310^{-2}$ \\
\hline to continental natural soil & $3.8910^{-9}$ & $2.3310^{-1}$ & $3.6010^{\circ}$ & $1.1710^{\circ}$ \\
\hline to continental agricultural soil & $1.5910^{-8}$ & $1.5810^{-6}$ & $3.6010^{0}$ & $1.1710^{0}$ \\
\hline \multicolumn{5}{|c|}{ DAMAGE LEVEL CHARACTERIZATION FACTORS } \\
\hline \multirow{3}{*}{ Type of emission } & \multirow{2}{*}{\multicolumn{2}{|c|}{$\begin{array}{l}\text { Human toxicity } \\
\text { [DALY/kg emitted] }\end{array}$}} & \multirow{2}{*}{\multicolumn{2}{|c|}{$\begin{array}{l}\text { Freshwater aq. ecotoxicity } \\
\text { [PDF.m3.day/kg emitted] }\end{array}$}} \\
\hline & & & & \\
\hline & DMC & DCE & $\mathrm{DMC}$ & DCE \\
\hline to household indoor air & $7.3510^{-6}$ & $7.5610^{-4}$ & $1.9010^{-1}$ & $6.0810^{-2}$ \\
\hline to industrial indoor air & $2.5010^{-1}$ & $2.6710^{-5}$ & $1.9010^{-1}$ & $6.0810^{-2}$ \\
\hline to urban air & $5.2510^{-8}$ & $6.4310^{-6}$ & $1.9010^{-1}$ & $6.0810^{-2}$ \\
\hline to continental rural air & $1.0610^{-8}$ & $2.1310^{-6}$ & $1.9010^{-1}$ & $6.0810^{-2}$ \\
\hline to continental freshwater & $2.3910^{-8}$ & $1.9610^{-5}$ & $6.7310^{\circ}$ & $7.5510^{\circ}$ \\
\hline to continental sea water & $6.6510^{-10}$ & $4.9710^{-1}$ & $1.1410^{-2}$ & $1.1610^{-2}$ \\
\hline to continental natural soil & $1.0510^{-8}$ & $2.9110^{-6}$ & $1.8010^{\circ}$ & $5.8610^{-1}$ \\
\hline to continental agricultural soil & $4.2910^{-8}$ & $1.9810^{-5}$ & $1.8010^{0}$ & $5.8610^{-1}$ \\
\hline
\end{tabular}


Table 7. Chemical analyses on solid waste from PHB extraction from microbial cells.

\begin{tabular}{|l|c|c|}
\hline PARAMETERS & Unit & Value \\
\hline $\mathrm{C}$ & $\%$ & 47.6 \\
\hline $\mathrm{H}$ & $\%$ & 9.6 \\
\hline $\mathrm{N}$ & $\%$ & 5.2 \\
\hline $\mathrm{S}$ & $\%$ & 0.1 \\
\hline $\mathrm{Cl}$ & $\%$ & 0.03 \\
\hline $\mathrm{DMC}$ & $\mathrm{mg} / \mathrm{kg}$ & 0.4 \\
\hline $\mathrm{Be}$ & $\mathrm{mg} / \mathrm{kg}$ & $<1$ \\
\hline $\mathrm{Al}$ & $\mathrm{mg} / \mathrm{kg}$ & 180.9 \\
\hline $\mathrm{V}$ & $\mathrm{mg} / \mathrm{kg}$ & 1.67 \\
\hline $\mathrm{Cr}$ & $\mathrm{mg} / \mathrm{kg}$ & 5.3 \\
\hline $\mathrm{Mn}$ & $\mathrm{mg} / \mathrm{kg}$ & 144.4 \\
\hline $\mathrm{Fe}$ & $\mathrm{mg} / \mathrm{kg}$ & 1092.8 \\
\hline $\mathrm{Co}$ & $\mathrm{mg} / \mathrm{kg}$ & 36.5 \\
\hline $\mathrm{Ni}$ & $\mathrm{mg} / \mathrm{kg}$ & 2.12 \\
\hline $\mathrm{Cu}$ & $\mathrm{mg} / \mathrm{kg}$ & 95.5 \\
\hline $\mathrm{Zn}$ & $\mathrm{mg} / \mathrm{kg}$ & 496 \\
\hline $\mathrm{As}$ & $\mathrm{mg} / \mathrm{kg}$ & $<1$ \\
\hline $\mathrm{Ag}$ & $\mathrm{mg} / \mathrm{kg}$ & 4.1 \\
\hline $\mathrm{Cd}$ & $\mathrm{mg} / \mathrm{kg}$ & $<0,5$ \\
\hline $\mathrm{Sb}$ & $\mathrm{mg} / \mathrm{kg}$ & $<1$ \\
\hline $\mathrm{Ba}$ & $\mathrm{mg} / \mathrm{kg}$ & 41.6 \\
\hline $\mathrm{Tl}$ & $\mathrm{mg} / \mathrm{kg}$ & $<1$ \\
\hline $\mathrm{Pb}$ & $\mathrm{mg} / \mathrm{kg}$ & 5.2 \\
\hline $\mathrm{Hg}$ & $\mathrm{mg} / \mathrm{kg}$ & $<0,2$ \\
\hline $\mathrm{Sn}$ & $\mathrm{mg} / \mathrm{kg}$ & 1.32 \\
\hline $\mathrm{HHV}$ & $\mathrm{J} / \mathrm{g}$ & 16,455 \\
\hline $\mathrm{LHV}$ & $\mathrm{J} / \mathrm{g}$ & 14,400 \\
\hline & & \\
\hline & & \\
\hline
\end{tabular}


Table 8 LCIA scores related to 'new extraction process' scenarios: extraction from microbial slurry + evaporation of the solvent (SlurryEvap), extraction from dried biomass + evaporation of the solvent (Dry-Evap), extraction from microbial slurry + addition of EtOH and precipitation (Slurry-Precip), extraction from dried biomass + addition of EtOH and precipitation (Dry-Precip). Reference scenario is extraction with 1,2-dichloroethane (DCE). FU is $1 \mathrm{~kg}$ of PHB ready for the product's manufacturing.

\begin{tabular}{|c|c|c|c|c|c|c|}
\hline Impact category & Unit & Slurry-Evap & Dry-Evap & Slurry-Precip & Dry-Precip & DCE \\
\hline GWP & $\mathrm{kg} \mathrm{CO}_{2} \mathrm{eq}$ & $7.010^{\circ}$ & $3.910^{\circ}$ & $1.110^{1}$ & $7.910^{\circ}$ & $6.310^{1}$ \\
\hline OD & kg CFC-11eq. & $2.510^{-1}$ & $6.410^{-9}$ & $2.910^{-1}$ & $4.810^{-8}$ & $1.610^{-6}$ \\
\hline HTC & CTUh & $2.610^{-8}$ & $2.010^{-9}$ & $3.810^{-8}$ & $1.510^{-8}$ & $1.710^{-1}$ \\
\hline HTnc & CTUh & $8.510^{-8}$ & $2.510^{-8}$ & $1.210^{-1}$ & $6.610^{-8}$ & $9.810^{-1}$ \\
\hline $\mathrm{FE}$ & CTUe & $1.810^{\circ}$ & $8.410^{-2}$ & $2.810^{0}$ & $1.110^{0}$ & $1.510^{1}$ \\
\hline$A C$ & Mole of $\mathrm{H}^{+}$eq. & $9.710^{-3}$ & $4.910^{-3}$ & $1.610^{-2}$ & $1.110^{-2}$ & $9.210^{-2}$ \\
\hline POF & kg NMVOC & $1.010^{-2}$ & $4.510^{-3}$ & $2.410^{-2}$ & $1.610^{-2}$ & $8.610^{-2}$ \\
\hline EuF & $\mathrm{kg} P$ eq. & $1.410^{-4}$ & $4.710^{-6}$ & $2.610^{-4}$ & $1.310^{-4}$ & $1.110^{-3}$ \\
\hline EuT & Mole of $\mathrm{N}$ eq. & $2.810^{-2}$ & $1.510^{-2}$ & $4.310^{-2}$ & $3.010^{-2}$ & $2.510^{-1}$ \\
\hline PM & $\mathrm{kg} \mathrm{PM}{ }_{2.5} \mathrm{eq}$. & $3.910^{-4}$ & $1.910^{-4}$ & $6.610^{-4}$ & $4.710^{-4}$ & $3.910^{-3}$ \\
\hline $\mathrm{IR}$ & kBq U235eq. & $5.110^{1}$ & $1.310^{\circ}$ & $6.410^{1}$ & $1.610^{1}$ & $4.510^{2}$ \\
\hline $\mathrm{RD}$ & kg Sb eq. & $1.610^{\circ}$ & $1.010^{\circ}$ & $3.110^{\circ}$ & $2.610^{\circ}$ & $2.010^{1}$ \\
\hline WD & $\mathrm{m}^{3}$ eq. & $1.010^{-5}$ & $1.610^{-6}$ & $1.410^{-5}$ & $6.010^{-6}$ & $6.410^{-5}$ \\
\hline
\end{tabular}




\section{Annex A}

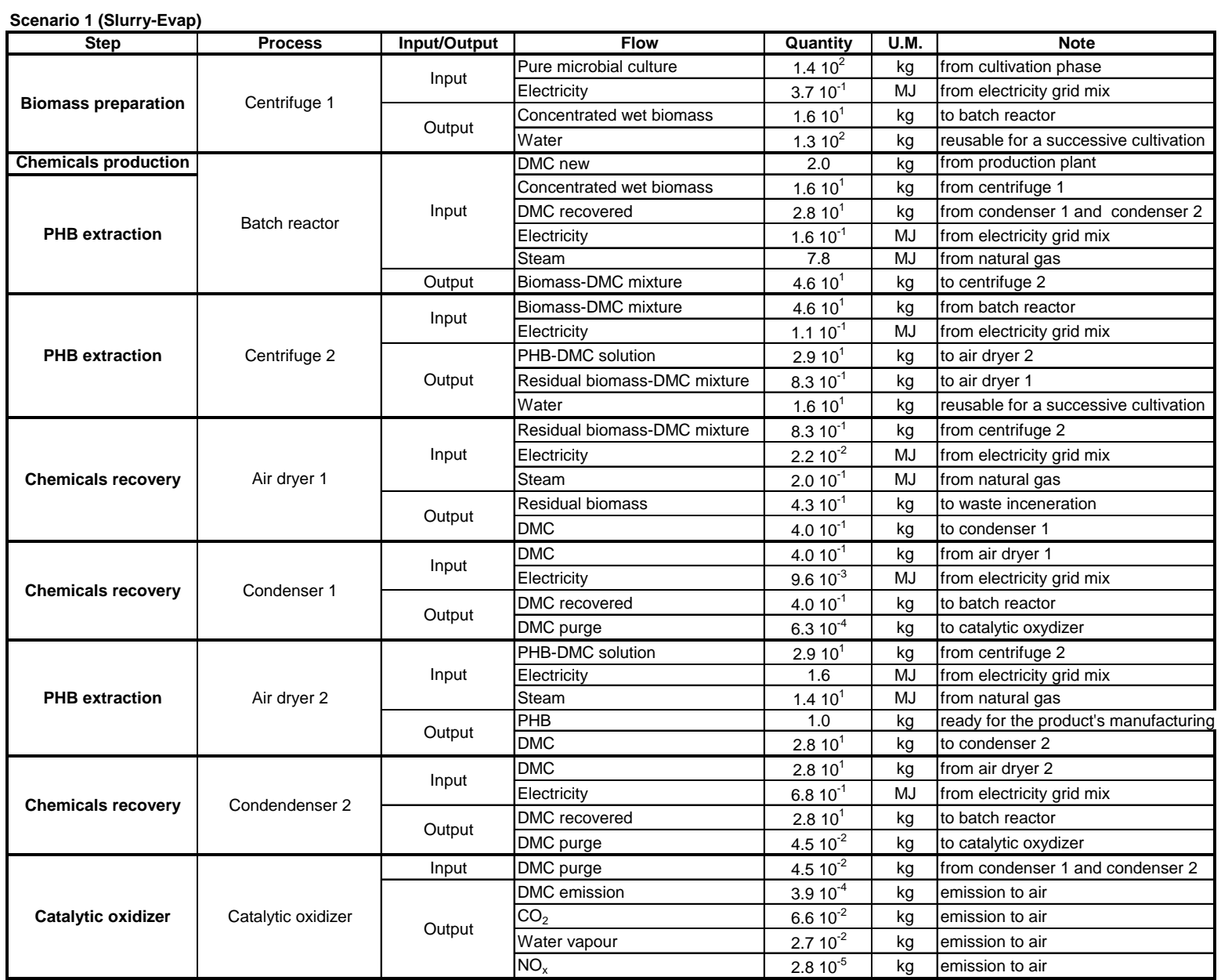


Annex B

Scenario 2 (Dry-Evap)

\begin{tabular}{|c|c|c|c|c|c|c|}
\hline Step & Process & Input/Output & Flow & Quantity & U.M. & Note \\
\hline \multirow{4}{*}{ Biomass preparation } & \multirow{4}{*}{ Centrifuge 1} & \multirow{2}{*}{ Input } & Pure microbial culture & $1.510^{2}$ & $\mathrm{~kg}$ & from cultivation phase \\
\hline & & & Electricity & $3.810^{-1}$ & $\mathrm{MJ}$ & from electricity grid mix \\
\hline & & \multirow{2}{*}{ Output } & Concentrated wet biomass & 8.9 & $\mathrm{~kg}$ & to batch reactor \\
\hline & & & Water & $1.410^{2}$ & $\mathrm{~kg}$ & reusable for a successive cultivation \\
\hline \multirow{5}{*}{ Biomass preparation } & \multirow{5}{*}{ Air dryer 1} & \multirow{3}{*}{ Input } & Concentrated wet biomass & 8.9 & $\mathrm{~kg}$ & from centrifuge 1 \\
\hline & & & \begin{tabular}{|l|} 
Electricity \\
\end{tabular} & 1.9 & $\mathrm{MJ}$ & from electricity grid mix \\
\hline & & & Steam & $1.710^{1}$ & MJ & from natural gas \\
\hline & & \multirow{2}{*}{ Output } & Dried biomass & 1.5 & $\mathrm{~kg}$ & to batch reactor \\
\hline & & & Water vapour & 7.5 & $\mathrm{~kg}$ & emission to air \\
\hline Chemicals production & \multirow{6}{*}{ Batch reactor } & \multirow{5}{*}{ Input } & DMC new & $5.110^{-2}$ & $\mathrm{~kg}$ & from production plant \\
\hline \multirow{5}{*}{ PHB extraction } & & & Dried biomass & 1.5 & $\mathrm{~kg}$ & from air dryer 1 \\
\hline & & & DMC recovered & $3.210^{1}$ & $\mathrm{~kg}$ & from condenser 1 and condenser 2 \\
\hline & & & Electricity & $1.110^{-1}$ & MJ & from electricity grid mix \\
\hline & & & Steam & 4.0 & MJ & from natural gas \\
\hline & & Output & Biomass-DMC mixture & $3.310^{1}$ & $\mathrm{~kg}$ & to centrifuge 2 \\
\hline \multirow{4}{*}{ PHB extraction } & \multirow{4}{*}{ Centrifuge 2} & \multirow{2}{*}{ Input } & Biomass-DMC mixture & $3.310^{1}$ & $\mathrm{~kg}$ & from batch reactor \\
\hline & & & Electricity & $7.910^{-2}$ & MJ & from electricity grid mix \\
\hline & & \multirow{2}{*}{ Output } & PHB-DMC solution & $3.210^{1}$ & $\mathrm{~kg}$ & to air dryer 3 \\
\hline & & & Residual biomass-DMC mixture & $9.510^{-1}$ & $\mathrm{~kg}$ & to air dryer 2 \\
\hline \multirow{5}{*}{ Chemicals recovery } & \multirow{5}{*}{ Air dryer 2} & \multirow{3}{*}{ Input } & Residual biomass-DMC mixture & $9.510^{-1}$ & $\mathrm{~kg}$ & from centrifuge 2 \\
\hline & & & \begin{tabular}{|l|} 
Electricity \\
\end{tabular} & $2.610^{-2}$ & $\mathrm{MJ}$ & from electricity grid mix \\
\hline & & & Steam & $2.310^{-1}$ & $\mathrm{MJ}$ & from natural gas \\
\hline & & \multirow{2}{*}{ Output } & Residual biomass & $4.910^{-1}$ & $\mathrm{~kg}$ & to waste inceneration \\
\hline & & & DMC & $4.610^{-1}$ & $\mathrm{~kg}$ & to condenser 1 \\
\hline \multirow{4}{*}{ Chemicals recovery } & \multirow{4}{*}{ Condenser 1} & \multirow{2}{*}{ Input } & DMC & $4.610^{-1}$ & $\mathrm{~kg}$ & from air dryer 2 \\
\hline & & & Electricity & $1.110^{-2}$ & MJ & from electricity grid mix \\
\hline & & \multirow{2}{*}{ Output } & DMC recovered & $4.610^{-1}$ & $\mathrm{~kg}$ & to batch reactor \\
\hline & & & DMC purge & $7.310^{-4}$ & $\mathrm{~kg}$ & to catalytic oxydizer \\
\hline \multirow{5}{*}{ PHB extraction } & & & PHB-DMC solution & $3.210^{1}$ & $\mathrm{~kg}$ & from centrifuge 2 \\
\hline & & Input & Electricity & 1.8 & $\mathrm{MJ}$ & from electricity grid mix \\
\hline & Air dryer 3 & & Steam & $1.610^{1}$ & MJ & from natural gas \\
\hline & & Outnut & PHB & 1.0 & $\mathrm{~kg}$ & ready for the product's manufacturing \\
\hline & & Output & DMC & $3.110^{1}$ & $\mathrm{~kg}$ & to condenser 2 \\
\hline & & Innut & DMC & $3.110^{1}$ & $\mathrm{~kg}$ & from air dryer 3 \\
\hline & & Imput & Electricity & $7.510^{-1}$ & MJ & from electricity grid mix \\
\hline Chemicals recovery & Condenser 2 & Outnut & DMC recovered & $3.110^{1}$ & $\mathrm{~kg}$ & to batch reactor \\
\hline & & Output & DMC purge & $5.010^{-2}$ & $\mathrm{~kg}$ & to catalytic oxydizer \\
\hline & & Input & DMC purge & $5.110^{-2}$ & $\mathrm{~kg}$ & from condenser 1 and condenser 2 \\
\hline & & & DMC emission & $2.710^{-4}$ & $\mathrm{~kg}$ & emission to air \\
\hline Catalytic oxidizer & Catalytic oxidizer & Putnu & $\mathrm{CO}_{2}$ & $7.410^{-2}$ & $\mathrm{~kg}$ & emission to air \\
\hline & & Output & Water vapour & $3.010^{-2}$ & $\mathrm{~kg}$ & emission to air \\
\hline & & & $\mathrm{NO}_{\mathrm{x}}$ & $3.210^{-5}$ & $\mathrm{~kg}$ & emission to air \\
\hline
\end{tabular}


Annex C

Scenario 3 (Slurry-Precip)

\begin{tabular}{|c|c|c|c|c|c|c|}
\hline Step & Process & Input/Output & Flow & Quantity & U.M. & Note \\
\hline \multirow{4}{*}{ Biomass preparation } & \multirow{4}{*}{ Centrifuge 1} & \multirow{2}{*}{ Input } & Pure microbial culture & $1.410^{2}$ & $\mathrm{~kg}$ & from cultivation phase \\
\hline & & & Electricity & $3.710^{-1}$ & MJ & from electricity grid mix \\
\hline & & \multirow{2}{*}{ Output } & Concentrated wet biomass & $1.610^{1}$ & $\mathrm{~kg}$ & to batch reactor \\
\hline & & & Water & $1.310^{2}$ & $\mathrm{~kg}$ & reusable for a successive cultivation \\
\hline Chemicals production & \multirow{6}{*}{ Batch reactor 1} & \multirow{5}{*}{ Input } & DMC new & 2.3 & $\mathrm{~kg}$ & from production plant \\
\hline \multirow{5}{*}{ PHB extraction } & & & Concentrated wet biomass & $1.610^{1}$ & $\mathrm{~kg}$ & from centrifuge 1 \\
\hline & & & DMC recovered & $2.810^{1}$ & $\mathrm{~kg}$ & from condenser 1 and pervaporation \\
\hline & & & \begin{tabular}{|l|} 
Electricity \\
\end{tabular} & $1.610^{-1}$ & MJ & from electricity grid mix \\
\hline & & & Steam & 7.8 & MJ & from natural gas \\
\hline & & Output & Biomass-DMC mixture & $4.610^{1}$ & $\mathrm{~kg}$ & to centrifuge 2 \\
\hline \multirow{5}{*}{ PHB extraction } & \multirow{5}{*}{ Centrifuge 2} & \multirow{2}{*}{ Input } & Biomass-DMC mixture & $4.610^{1}$ & $\mathrm{~kg}$ & from batch reactor 1 \\
\hline & & & Electricity & $1.110^{-1}$ & MJ & from electricity grid mix \\
\hline & & \multirow{3}{*}{ Output } & PHB-DMC solution & $2.910^{1}$ & $\mathrm{~kg}$ & to batch reactor 2 \\
\hline & & & Residual biomass-DMC mixture & $8.310^{-1}$ & $\mathrm{~kg}$ & to air dryer 1 \\
\hline & & & Water & $1.610^{1}$ & $\mathrm{~kg}$ & reusable for a successive cultivation \\
\hline \multirow{5}{*}{ Chemicals recovery } & \multirow{5}{*}{ Air dryer 1} & \multirow{3}{*}{ Input } & Residual biomass-DMC mixture & $8.310^{-1}$ & $\mathrm{~kg}$ & from centrifuge 2 \\
\hline & & & Electricity & $2.210^{-2}$ & MJ & from electricity grid mix \\
\hline & & & Steam & $2.010^{-1}$ & MJ & from natural gas \\
\hline & & \multirow{2}{*}{ Output } & Residual biomass & $4.310^{-1}$ & $\mathrm{~kg}$ & to waste inceneration \\
\hline & & & DMC & $4.010^{-1}$ & $\mathrm{~kg}$ & to condenser 1 \\
\hline \multirow{4}{*}{ Chemicals recovery } & \multirow{4}{*}{ Condenser 1} & Input & DMC & $4.010^{-1}$ & $\mathrm{~kg}$ & from air dryer 1 \\
\hline & & Input & Electricity & $9.610^{-3}$ & MJ & from electricity grid mix \\
\hline & & Outnut & DMC recovered & $4.010^{-1}$ & $\mathrm{~kg}$ & to batch reactor 1 \\
\hline & & Output & DMC purge & $6.310^{-4}$ & $\mathrm{~kg}$ & to catalytic oxydizer \\
\hline Chemicals production & & & EtOH new & $2.210^{-1}$ & $\mathrm{~kg}$ & from production plant \\
\hline & & Input & PHB-DMC solution & $2.910^{1}$ & $\mathrm{~kg}$ & from centrifuge 2 \\
\hline DHP ortration & Batch reactor 2 & & EtOH recovered & $2.210^{1}$ & $\mathrm{~kg}$ & from pervaporation \\
\hline PHB extraction & & & Electricity & $2.010^{-1}$ & MJ & from electricity grid mix \\
\hline & & Output & PHB-DMC-EtOH mixture & $5.110^{1}$ & $\mathrm{~kg}$ & to centrifuge 3 \\
\hline & & Innut t 25 & PHB-DMC-EtOH mixture & $5.110^{1}$ & $\mathrm{~kg}$ & from batch reactor 2 \\
\hline PHB extraction & Centrifuge 3 & Input & \begin{tabular}{|l|} 
Electricity \\
\end{tabular} & $1.410^{-1}$ & MJ & from electricity grid mix \\
\hline PHB extraction & Centringe 3 & Outnut & PHB-DMC-EtOH concentrated mixture & 2.0 & $\mathrm{~kg}$ & to air dryer 2 \\
\hline & & Output & DMC-EtOH solution & $4.910^{1}$ & $\mathrm{~kg}$ & to pervaporation \\
\hline & & & PHB-DMC-EtOH concentrated mixture & 2.0 & $\mathrm{~kg}$ & from centrifuge 3 \\
\hline & & Input & Electricity & $9.810^{-2}$ & $\mathrm{MJ}$ & from electricity grid mix \\
\hline PHB extraction & Air dryer 2 & & Steam & $8.810^{-1}$ & $\mathrm{MJ}$ & from natural gas \\
\hline & & Outnut & PHB & 1.0 & $\mathrm{~kg}$ & ready for the product's manufacturing \\
\hline & & tutput & DMC-EtOH solution & 1.0 & $\mathrm{~kg}$ & to condenser 2 \\
\hline & & Innut & DMC-EtOH solution & 1.0 & $\mathrm{~kg}$ & from air dryer 2 \\
\hline & & Input & Electricity & $4.210^{-2}$ & MJ & from electricity grid mix \\
\hline Chemicals recovery & Condenser 2 & & DMC-EtOH solution recovered & 1.0 & $\mathrm{~kg}$ & to pervaporation \\
\hline & & Output & DMC purge & $2.210^{-3}$ & $\mathrm{~kg}$ & to catalytic oxydizer \\
\hline & & & EtOH purge & $1,710^{-3}$ & $\mathrm{~kg}$ & to catalytic oxydizer \\
\hline & & & DMC-EtOH solution & $5,010^{1}$ & $\mathrm{~kg}$ & from centifuge 3 and condenser 2 \\
\hline & & Input & Electricity & $1.010^{1}$ & MJ & from electricity grid mix \\
\hline & & & Steam & $2.710^{1}$ & MJ & from natural gas \\
\hline Chemicals recovery & Pervaporation & & DMC recovered & $2.810^{1}$ & $\mathrm{~kg}$ & to batch reactor 1 \\
\hline & & Outnut & EtOH recovered & $2.210^{1}$ & $\mathrm{~kg}$ & to batch reactor 2 \\
\hline & & Uutput & DMC purge & $2.810^{-1}$ & $\mathrm{~kg}$ & to catalytic oxydizer \\
\hline & & & EtOH purge & $2.210^{-1}$ & $\mathrm{~kg}$ & to catalytic oxydizer \\
\hline & & Innut & DMC purge & $2.810^{-1}$ & $\mathrm{~kg}$ & from condensers 1-2 and pervaporation \\
\hline & & Input & EtOH purge & $2,210^{-1}$ & $\mathrm{~kg}$ & from condenser 2 and pervaporation \\
\hline & & & DMC emission & $1.610^{-2}$ & $\mathrm{~kg}$ & emission to air \\
\hline Catalytic oxidizer & Catalytic oxidizer & & EtOH emission & $1.210^{-2}$ & $\mathrm{~kg}$ & emission to air \\
\hline & & Output & $\mathrm{CO}_{2}$ & $8.010^{-1}$ & $\mathrm{~kg}$ & emission to air \\
\hline & & & Water vapour & $4.110^{-1}$ & $\mathrm{~kg}$ & emission to air \\
\hline & & & $\mathrm{NO}_{\mathrm{x}}$ & $3.010^{-4}$ & $\mathrm{~kg}$ & emission to air \\
\hline
\end{tabular}


Annex D

Scenario 4 (Dry-Precip)

\begin{tabular}{|c|c|c|c|c|c|c|}
\hline Step & Process & Input/Output & Flow & Quantity & U.M. & Note \\
\hline \multirow{4}{*}{ Biomass preparation } & \multirow{4}{*}{ Centrifuge 1} & \multirow{2}{*}{ Input } & Pure microbial culture & $1.510^{2}$ & $\mathrm{~kg}$ & from cultivation phase \\
\hline & & & Electricity & $3,810^{-1}$ & $\mathrm{MJ}$ & from electricity grid mix \\
\hline & & \multirow{2}{*}{ Output } & Concentrated wet biomass & 8.9 & $\mathrm{~kg}$ & to batch reactor \\
\hline & & & Water & $1.410^{2}$ & $\mathrm{~kg}$ & reusable for a successive cultivation \\
\hline \multirow{5}{*}{ Biomass preparation } & \multirow{5}{*}{ Air dryer 1} & \multirow{3}{*}{ Input } & Concentrated wet biomass & 8.9 & $\mathrm{~kg}$ & from centrifuge 1 \\
\hline & & & Electricity & 1.9 & MJ & from electricity grid mix \\
\hline & & & Steam & $1.710^{1}$ & MJ & from natural gas \\
\hline & & \multirow[b]{2}{*}{ Output } & Dried biomass & 1.5 & $\mathrm{~kg}$ & to batch reactor \\
\hline & & & Water vapour & 7.5 & $\mathrm{~kg}$ & emission to air \\
\hline Chemicals production & \multirow{6}{*}{ Batch reactor 1} & \multirow{5}{*}{ Input } & DMC new & $3.210^{-1}$ & $\mathrm{~kg}$ & from production plant \\
\hline \multirow{5}{*}{ PHB extraction } & & & Dried biomass & 1.5 & $\mathrm{~kg}$ & from air dryer 1 \\
\hline & & & DMC recovered & $3.210^{1}$ & $\mathrm{~kg}$ & from condenser 1 and pervaporation \\
\hline & & & Electricity & $1.110^{-1}$ & $\mathrm{MJ}$ & from electricity grid mix \\
\hline & & & Steam & 4.0 & MJ & from natural gas \\
\hline & & Output & Biomass-DMC mixture & $3.310^{1}$ & $\mathrm{~kg}$ & to centrifuge 2 \\
\hline \multirow{4}{*}{ PHB extraction } & \multirow{4}{*}{ Centrifuge 2} & \multirow{2}{*}{ Input } & Biomass-DMC mixture & $3.310^{1}$ & $\mathrm{~kg}$ & from batch reactor 1 \\
\hline & & & Electricity & $7.910^{-2}$ & $\mathrm{MJ}$ & from electricity grid mix \\
\hline & & \multirow{2}{*}{ Output } & PHB-DMC solution & $3.210^{1}$ & $\mathrm{~kg}$ & to reactor batch 2 \\
\hline & & & Residual biomass-DMC mixture & $9.510^{-1}$ & $\mathrm{~kg}$ & to air dryer 2 \\
\hline & & & Residual biomass-DMC mixture & $9.510^{-1}$ & $\mathrm{~kg}$ & from centrifuge 2 \\
\hline & & Input & Electricity & $2.610^{-2}$ & $\mathrm{MJ}$ & from electricity grid mix \\
\hline Chemicals recovery & Air dryer 2 & & Steam & $2.310^{-1}$ & MJ & from natural gas \\
\hline & & Outnut t S & Residual biomass & $4.910^{-1}$ & $\mathrm{~kg}$ & to waste inceneration \\
\hline & & Uutput & DMC & $4.610^{-1}$ & $\mathrm{~kg}$ & to condenser 1 \\
\hline & & Input & DMC & $4.610^{-1}$ & $\mathrm{~kg}$ & from air dryer 2 \\
\hline & & Input & Electricity & $1.110^{-2}$ & $\mathrm{MJ}$ & from electricity grid mix \\
\hline Chemicals recovery & Condenser 1 & & DMC recovered & $4.610^{-1}$ & $\mathrm{~kg}$ & to batch reactor 1 \\
\hline & & Output & DMC purge & $7.310^{-4}$ & $\mathrm{~kg}$ & to catalytic oxydizer \\
\hline Chemicals production & & & EtOH new & $2.310^{-1}$ & $\mathrm{~kg}$ & from production plant \\
\hline & & Innut & PHB-DMC solution & $3.210^{1}$ & $\mathrm{~kg}$ & from centrifuge 2 \\
\hline DHR ovtraction & Batch reactor 2 & Input & EtOH recovered & $2.310^{1}$ & $\mathrm{~kg}$ & from pervaporation \\
\hline PHB extraction & & & Electricity & $2.210^{-1}$ & $\mathrm{MJ}$ & from electricity grid mix \\
\hline & & Output & PHB-DMC-EtOH mixture & $5.610^{1}$ & $\mathrm{~kg}$ & to centrifuge 3 \\
\hline & & Input & PHB-DMC-EtOH mixture & $5.610^{1}$ & $\mathrm{~kg}$ & from batch reactor 2 \\
\hline PHB extraction & Centrifure 3 & Input & Electricity & $1.510^{-1}$ & $\mathrm{MJ}$ & from electricity grid mix \\
\hline r MD extraction & o & & PHB-DMC-EtOH concentrated mixture & 2.0 & $\mathrm{~kg}$ & to air dryer 3 \\
\hline & & Output & DMC+EtOH solution & $5.410^{1}$ & $\mathrm{~kg}$ & to pervaporation \\
\hline & & & PHB-DMC-EtOH concentrated mixture & 2.0 & $\mathrm{~kg}$ & from centrifuge 3 \\
\hline & & Input & Electricity & $9.710^{-2}$ & $\mathrm{MJ}$ & from electricity grid mix \\
\hline PHB extraction & Air dryer 3 & & Steam & $8.610^{-1}$ & MJ & from natural gas \\
\hline & & Outnut & PHB & 1.0 & $\mathrm{~kg}$ & ready for the product's manufacturing \\
\hline & & Uutput & DMC-EtOH solution & 1.0 & $\mathrm{~kg}$ & to condenser 2 \\
\hline & & Input & DMC-EtOH solution & 1.0 & $\mathrm{~kg}$ & from air dryer 3 \\
\hline & & Input & \begin{tabular}{|l|} 
Electricity \\
\end{tabular} & 1.0 & $\mathrm{MJ}$ & from electricity grid mix \\
\hline Chemicals recovery & Condenser 2 & & DMC-EtOH solution recovered & 1.0 & $\mathrm{~kg}$ & to pervaporation \\
\hline & & Output & DMC purge & $2.210^{-3}$ & $\mathrm{~kg}$ & to catalytic oxydizer \\
\hline & & & EtOH purge & $1.610^{-3}$ & $\mathrm{~kg}$ & to catalytic oxydizer \\
\hline & & & DMC-EtOH solution & $5.510^{1}$ & $\mathrm{~kg}$ & from centifuge 3 and condenser 2 \\
\hline & & Input & Electricity & $1.110^{1}$ & $\mathrm{MJ}$ & from electricity grid mix \\
\hline & & & Steam & $2.810^{1}$ & $\mathrm{MJ}$ & from natural gas \\
\hline Chemicals recovery & Pervaporation & & DMC recovered & $3.110^{1}$ & $\mathrm{~kg}$ & to batch reactor 1 \\
\hline & & & EtOH recovered & $2.310^{1}$ & $\mathrm{~kg}$ & to batch reactor 2 \\
\hline & & Output & DMC purge & $3.110^{-1}$ & $\mathrm{~kg}$ & to catalytic oxydizer \\
\hline & & & EtOH purge & $2.310^{-1}$ & $\mathrm{~kg}$ & to catalytic oxydizer \\
\hline & & Innut & DMC purge & $3.210^{-1}$ & $\mathrm{~kg}$ & from condensers 1-2 and pervaporation \\
\hline & & Input & EtOH purge & $2.310^{-1}$ & $\mathrm{~kg}$ & from condenser 2 and pervaporation \\
\hline & & & DMC emission & $1.110^{-2}$ & $\mathrm{~kg}$ & emission to air \\
\hline Catalytic oxidizer & Catalytic oxidizer & & EtOH emission & $8.110^{-3}$ & $\mathrm{~kg}$ & emission to air \\
\hline & & Output & $\mathrm{CO}_{2}$ & $8.810^{-1}$ & $\mathrm{~kg}$ & emission to air \\
\hline & & & Water vapour & $4.510^{-1}$ & $\mathrm{~kg}$ & emission to air \\
\hline & & & $\mathrm{NO}_{\mathrm{x}}$ & $3.310^{-4}$ & $\mathrm{~kg}$ & emission to air \\
\hline
\end{tabular}


Annex E

Scenario 5 (DCE)

\begin{tabular}{|c|c|c|c|c|c|c|}
\hline Step & Process & Input/Output & Flow & Quantity & U.M. & Note \\
\hline \multirow{4}{*}{ Biomass preparation } & \multirow{4}{*}{ Centrifuge 1} & \multirow{2}{*}{ Input } & Pure microbial culture & $1.510^{2}$ & $\mathrm{~kg}$ & from cultivation phase \\
\hline & & & Electricity & $3.910^{-1}$ & $\mathrm{MJ}$ & from electricity grid mix \\
\hline & & \multirow{2}{*}{ Output } & Concentrated wet biomass & 9.1 & $\mathrm{~kg}$ & to batch reactor \\
\hline & & & Water & $1.410^{2}$ & $\mathrm{~kg}$ & reusable for a successive cultivation \\
\hline \multirow{5}{*}{ Biomass preparation } & \multirow{5}{*}{ Air dryer 1} & \multirow{3}{*}{ Input } & Concentrated wet biomass & 9.1 & $\mathrm{~kg}$ & from centrifuge 1 \\
\hline & & & Electricity & 1.9 & $\mathrm{MJ}$ & from electricity grid mix \\
\hline & & & Steam & $1.710^{1}$ & MJ & from natural gas \\
\hline & & \multirow{2}{*}{ Output } & Dried biomass & 1.5 & $\mathrm{~kg}$ & to batch reactor \\
\hline & & & Water vapour & 7.6 & $\mathrm{~kg}$ & emission to air \\
\hline Chemicals production & \multirow{6}{*}{ Batch reactor 1} & \multirow{5}{*}{ Input } & DCE new & $9.510^{-1}$ & $\mathrm{~kg}$ & from production plant \\
\hline \multirow{5}{*}{ PHB extraction } & & & Dried biomass & 1.5 & $\mathrm{~kg}$ & from air dryer 1 \\
\hline & & & DCE recovered & $9.410^{1}$ & $\mathrm{~kg}$ & from condenser 1 and pervaporation \\
\hline & & & Electricity & $7.010^{-2}$ & $\mathrm{MJ}$ & from electricity grid mix \\
\hline & & & Steam & 7.3 & $\mathrm{MJ}$ & from natural gas \\
\hline & & Output & Biomass-DCE mixture & $9.710^{1}$ & $\mathrm{~kg}$ & to centrifuge 2 \\
\hline \multirow{4}{*}{ PHB extraction } & \multirow{4}{*}{ Centrifuge 2} & \multirow{2}{*}{ Input } & Biomass-DCE mixture & $9.710^{1}$ & $\mathrm{~kg}$ & from batch reactor 1 \\
\hline & & & Electricity & $2.010^{-1}$ & $\mathrm{MJ}$ & from electricity grid mix \\
\hline & & Outnut & PHB-DCE solution & $9.510^{1}$ & $\mathrm{~kg}$ & to reactor batch 2 \\
\hline & & Output & \begin{tabular}{|l} 
Residual biomass-DCE mixture \\
\end{tabular} & 1.0 & $\mathrm{~kg}$ & to air dryer 2 \\
\hline & & & Residual biomass-DCE mixture & 1.0 & $\mathrm{~kg}$ & from centrifuge 2 \\
\hline & & Input & Electricity & $2.510^{-2}$ & $\mathrm{MJ}$ & from electricity grid mix \\
\hline Chemicals recovery & Air dryer 2 & & Steam & $2.210^{-1}$ & $\mathrm{MJ}$ & from natural gas \\
\hline & & Outnut & Residual biomass & $5.210^{-1}$ & $\mathrm{~kg}$ & to waste inceneration \\
\hline & & Uatput & DCE & $5.110^{-1}$ & $\mathrm{~kg}$ & to condenser 1 \\
\hline & & Innut & DCE & $5.110^{-1}$ & $\mathrm{~kg}$ & from air dryer 2 \\
\hline & & Input & Electricity & $1.110^{-2}$ & $\mathrm{MJ}$ & from electricity grid mix \\
\hline Chemicals recovery & Condenser 1 & Output & DCE recovered & $5.110^{-1}$ & $\mathrm{~kg}$ & to batch reactor 1 \\
\hline & & Output & DCE purge & $2.510^{-3}$ & $\mathrm{~kg}$ & to catalytic oxydizer \\
\hline Chemicals production & & & Methanol-water solution new & 3.1 & $\mathrm{~kg}$ & from production plant \\
\hline & & 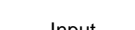 & PHB-DCE solution & $9.510^{1}$ & $\mathrm{~kg}$ & from centrifuge 2 \\
\hline PHR extraction & Batch reactor 2 & Input & Methanol-water solution recovered & $3.110^{2}$ & $\mathrm{~kg}$ & from pervaporation \\
\hline Pno extraction & & & Electricity & 1.6 & $\mathrm{MJ}$ & from electricity grid mix \\
\hline & & Output & PHB-DCE-methanol-water mixture & $4.110^{2}$ & $\mathrm{~kg}$ & to centrifuge 3 \\
\hline & & Input & PHB-DCE-methanol-water mixture & $4.110^{2}$ & $\mathrm{~kg}$ & from batch reactor 2 \\
\hline PHR extraction & Centrifuge 3 & & Electricity & 1.2 & $\mathrm{MJ}$ & from electricity grid mix \\
\hline & & Outnut & PHB-DCE-methanol-water concentrated mixture & 2.0 & $\mathrm{~kg}$ & to air dryer 3 \\
\hline & & Output & DCE-methanol-water solution & $4.110^{2}$ & $\mathrm{~kg}$ & to pervaporation \\
\hline & & & PHB-DCE-methanol-water concentrated mixture & 2.0 & $\mathrm{~kg}$ & from centrifuge 3 \\
\hline & & Input & Electricity & $2.410^{-1}$ & $\mathrm{MJ}$ & from electricity grid mix \\
\hline PHB extraction & Air dryer 3 & & Steam & 2.2 & $\mathrm{MJ}$ & from natural gas \\
\hline & & Outnut & $\mathrm{PHB}$ & 1.0 & $\mathrm{~kg}$ & ready for the product's manufacturing \\
\hline & & Uutput & DCE-methanol-water solution & 1.0 & $\mathrm{~kg}$ & to condenser 2 \\
\hline & & Innut & DCE-methanol-water solution & 1.0 & $\mathrm{~kg}$ & from air dryer 3 \\
\hline & & Input & Electricity & $1.010^{-1}$ & MJ & from electricity grid mix \\
\hline Chemicals recovery & Condenser 2 & & DCE-methanol-water solution recovered & $9.910^{-1}$ & $\mathrm{~kg}$ & to pervaporation \\
\hline & & Output & DCE purge & $1.710^{-3}$ & $\mathrm{~kg}$ & to catalytic oxydizer \\
\hline & & & Methanol-water purge & $5.710^{-3}$ & $\mathrm{~kg}$ & to catalytic oxydizer \\
\hline & & & DCE-methanol-water solution & $4.110^{2}$ & $\mathrm{~kg}$ & from centifuge 3 and condenser 2 \\
\hline & & Input & Electricity & $1.110^{2}$ & $\mathrm{MJ}$ & from electricity grid mix \\
\hline & & & Steam & $5.010^{2}$ & $\mathrm{MJ}$ & from natural gas \\
\hline Chemicals recovery & Pervaporation & & 1,2-dichloroethane (DCE) & $9.410^{1}$ & $\mathrm{~kg}$ & to batch reactor 1 \\
\hline & & Outnut & Methanol-water solution & $3.110^{2}$ & $\mathrm{~kg}$ & to batch reactor 2 \\
\hline & & Output & DCE purge & $9.410^{-1}$ & $\mathrm{~kg}$ & to catalytic oxydizer \\
\hline & & & \begin{tabular}{|l|} 
Methanol-water purge \\
\end{tabular} & 3.1 & $\mathrm{~kg}$ & to catalytic oxydizer \\
\hline & & Input & DCE purge & $9.510^{-1}$ & $\mathrm{~kg}$ & from condensers $1-2$ and pervaporation \\
\hline & & mput & Methanol-water purge & 3.1 & $\mathrm{~kg}$ & from condenser 2 and pervaporation \\
\hline & & & DCE emission & $4.710^{-3}$ & $\mathrm{~kg}$ & emission to air \\
\hline Catalytic oxidizer & Catalvtic oxidizer & & Metanolo emission & $1.210^{-2}$ & $\mathrm{~kg}$ & emission to air \\
\hline Catalytic oxiaizer & Ualalytic oxialzet & Output & $\mathrm{CO}_{2}$ & 3.3 & $\mathrm{~kg}$ & emission to air \\
\hline & & & Water vapour & 3.4 & $\mathrm{~kg}$ & emission to air \\
\hline & & & $\mathrm{NO}_{\mathrm{x}}$ & $1.510^{-3}$ & $\mathrm{~kg}$ & emission to air \\
\hline & & & Other emissions to air & N.R. & $\mathrm{kg}$ & emission to air (from EEA, 2013) \\
\hline
\end{tabular}




\begin{tabular}{|c|c|c|c|c|c|}
\hline ID & CHEMICALS & $\begin{array}{c}\text { CAS } \\
\text { NUMBER }\end{array}$ & ID & CHEMICALS & CAS NUMBER \\
\hline 1 & 1,1-dichloroethene & $75-35-4$ & 22 & tetrachloroethylene & $127-18-4$ \\
\hline 2 & chloromethane & $74-87-3$ & 23 & chlorobenzene & $108-90-7$ \\
\hline 3 & vinyl chloride & $75-01-4$ & 24 & ethylbenzene & $100-41-4$ \\
\hline 4 & dichloromethane & $75-09-2$ & 25 & meta- and para-xylene & $N / A^{\S}$ \\
\hline 5 & 1,2-dichloroethene trans & $156-60-5$ & 26 & bromoform & $75-25-2$ \\
\hline 6 & tert-butyl methyl ether & 1634-04-4 & 27 & styrene & $100-42-5$ \\
\hline 7 & 1,1-dichloroethane & $75-34-3$ & 28 & $\begin{array}{l}1,1,2,2- \\
\text { tetrachloroethane }\end{array}$ & $79-34-5$ \\
\hline 8 & 1,2-dichloroethene cis & $156-59-2$ & 29 & o- xylene & $95-47-6$ \\
\hline 9 & chloroform & $67-66-3$ & 30 & 1,2,3-trichloropropane & $96-18-4$ \\
\hline 10 & tert-butyl ethyl ether & $637-92-3$ & 31 & isopropylbenzene & $98-82-8$ \\
\hline 11 & 1,2-dichloroethane & $107-06-2$ & 32 & 2-chlorotoluene & $95-49-8$ \\
\hline 12 & 1,1,1-trichloroethane & $71-55-6$ & 33 & 4-chlorotoluene & $106-43-4$ \\
\hline 13 & tetrachloromethane & $56-23-5$ & 34 & 1,3-dichlorobenzene & $541-73-1$ \\
\hline 14 & benzene & $71-43-2$ & 35 & 1,4-dichlorobenzene & $106-46-7$ \\
\hline 15 & 1,2-dichloropropane & $78-87-5$ & 36 & 1,2-dichlorobenzene & $95-50-1$ \\
\hline 16 & 1,1,2-trichlorethylene & $79-01-6$ & 37 & nitrobenzene & $98-95-3$ \\
\hline 17 & bromodichloromethane & $75-27-4$ & 38 & naphthalene & $91-20-3$ \\
\hline 18 & 1,1,2-trichloroethane & $79-00-5$ & 39 & 1,2,4-trichlorobenzene & $120-82-1$ \\
\hline 19 & toluene & $108-88-3$ & 40 & $\begin{array}{l}\text { Hexachloro-1,3- } \\
\text { butadiene }\end{array}$ & $87-68-3$ \\
\hline 20 & dibromochloromethane & $124-48-1$ & 41 & 2-methylnaphthalene & $91-57-6$ \\
\hline 21 & 1,2-dibromoethane & $106-93-4$ & 42 & 1-methylnaphthalene & $90-12-0$ \\
\hline
\end{tabular}




\section{Figure captions}

Fig. 1: Process block diagram of each production scenario.

Fig. 2: Process contributions to GWP, AC, EuT, EuM and POF of each considered step: biomass preparation, chemical production, PHB extraction, chemicals recovery, catalytic oxidation and solid waste treatment (FU: $1 \mathrm{~kg}$ of $\mathrm{PHB})$.

Fig. 3: Process contributions to PM, HTnc, RD and WD of each considered step: biomass preparation, chemical production, PHB extraction, chemicals recovery, catalytic oxidation and solid waste treatment (FU: $1 \mathrm{~kg}$ of PHB).

Fig. 4: Process contributions to EuF, FE, HTc, IR and OD of each considered step: biomass preparation, chemical production, PHB extraction, chemicals recovery, catalytic oxidation and solid waste treatment (FU: $1 \mathrm{~kg}$ of PHB). 
Fig. 1

Scenario 1 (Slurry-Evap)

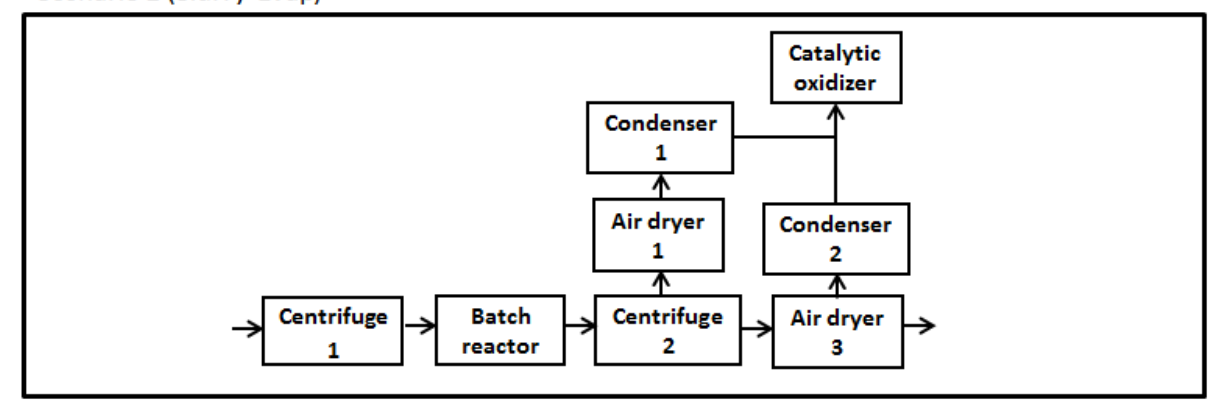

Scenario 2 (Dry-Evap)

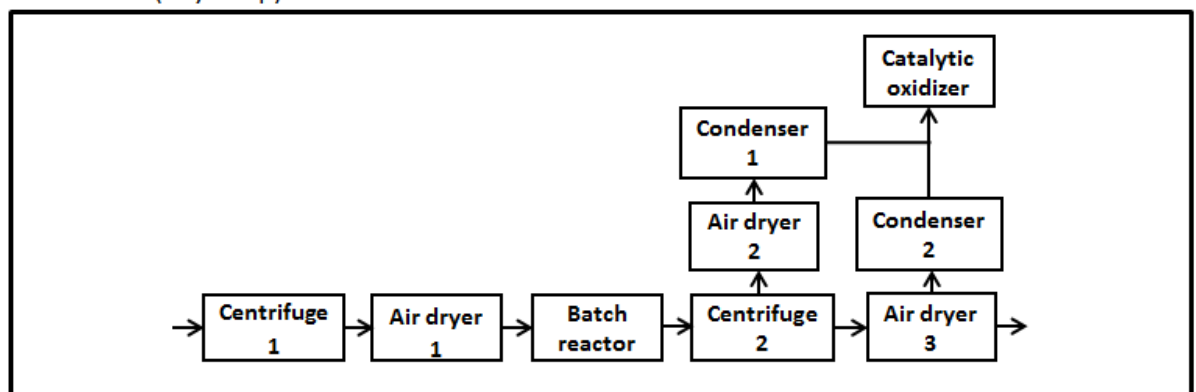

Scenario 3 (Slurry-Precip)

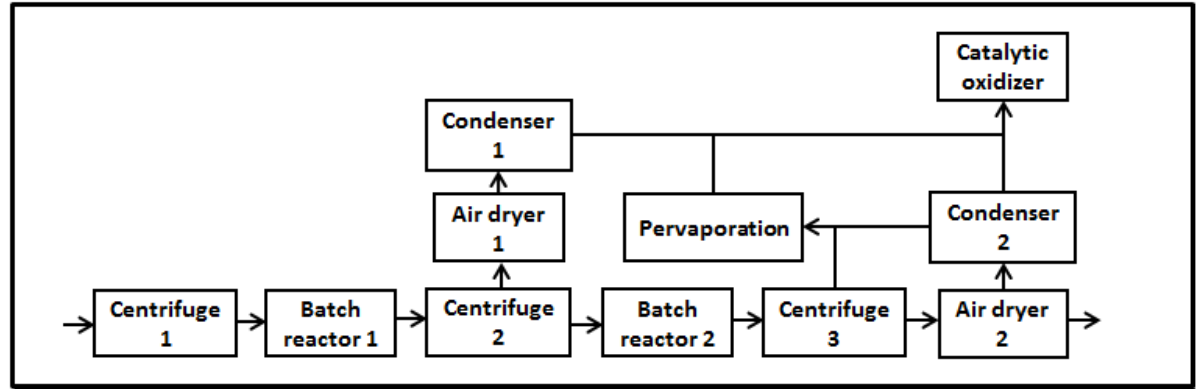

Scenario 4 (Dry-Precip)

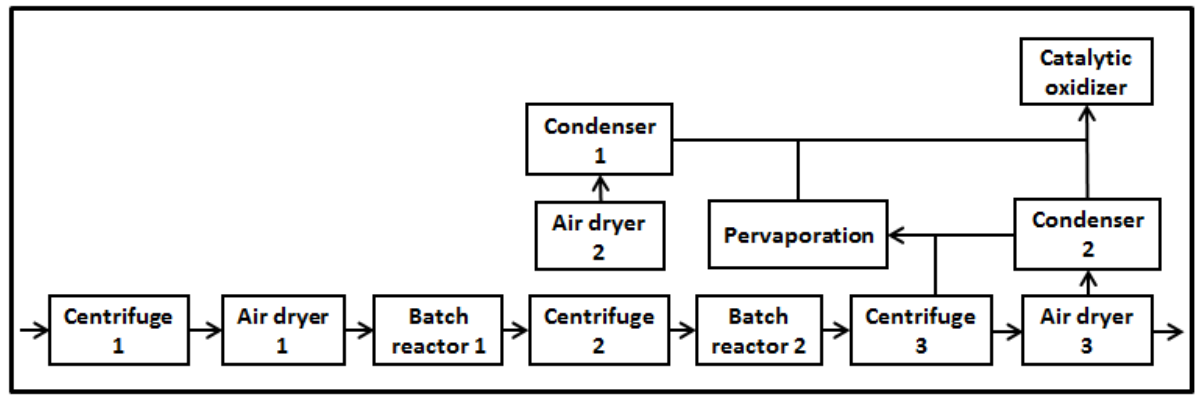

Scenario 5 (DCE)

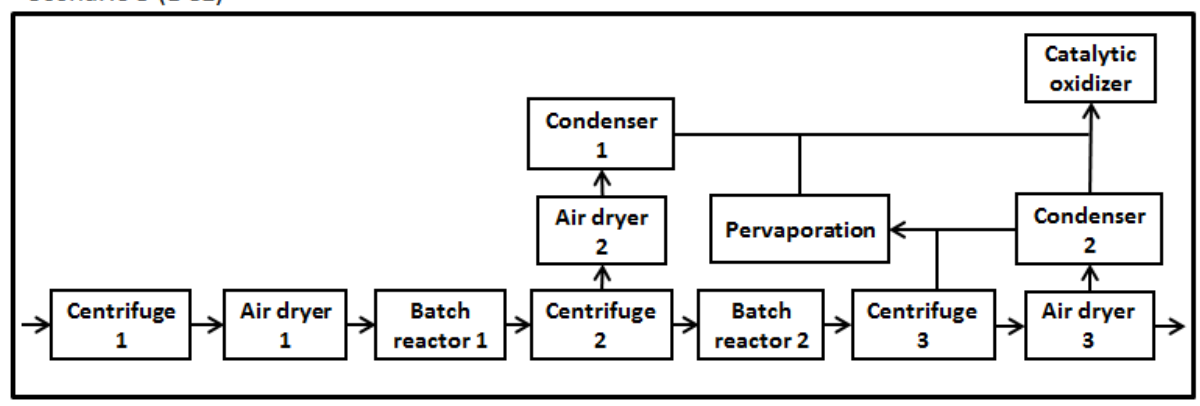


Fig. 2

Climate change excl biogenic carbon

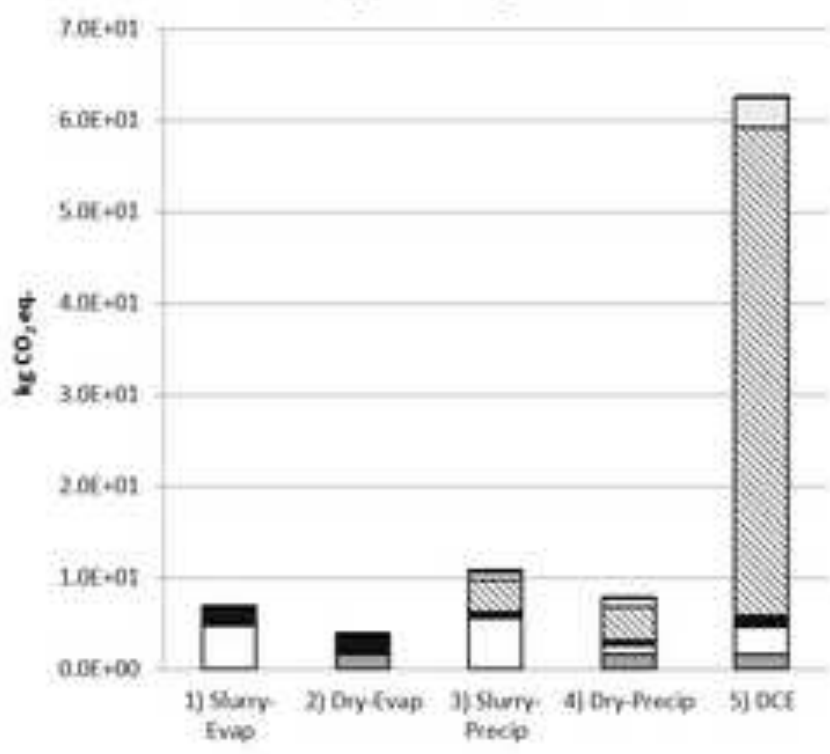

Eutrophication terrestrial

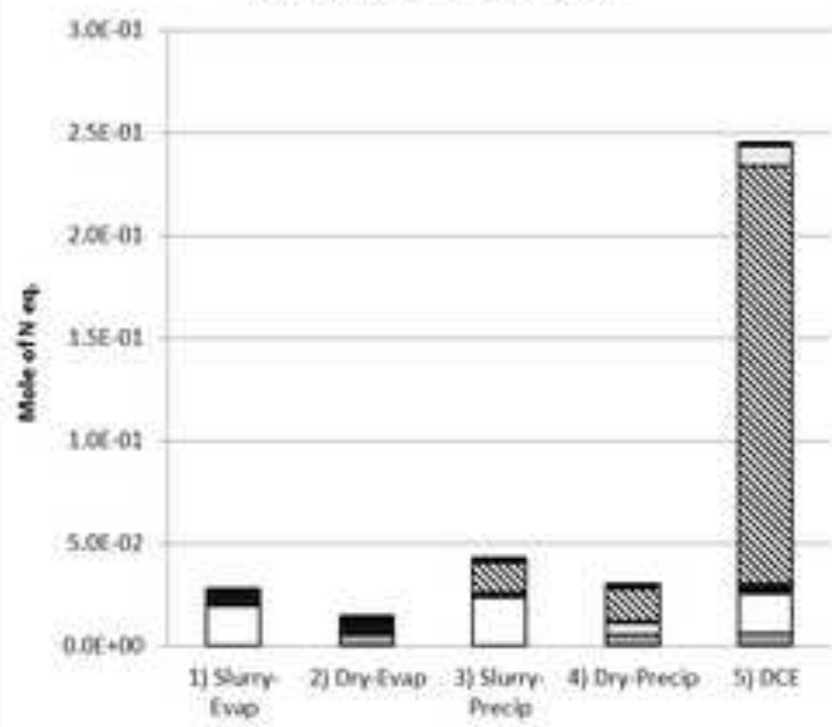

Photochemical ozone formation

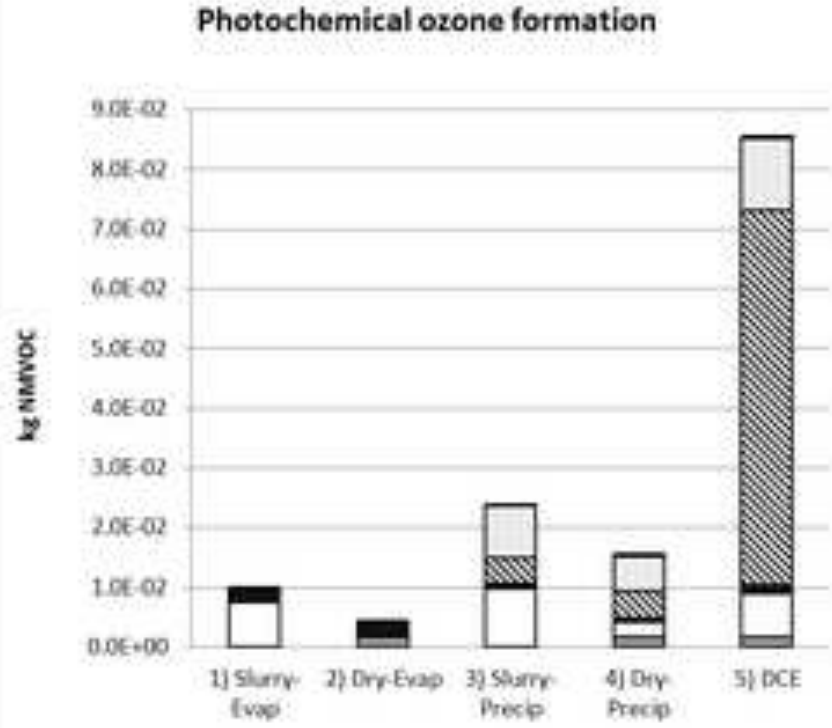

Acidification
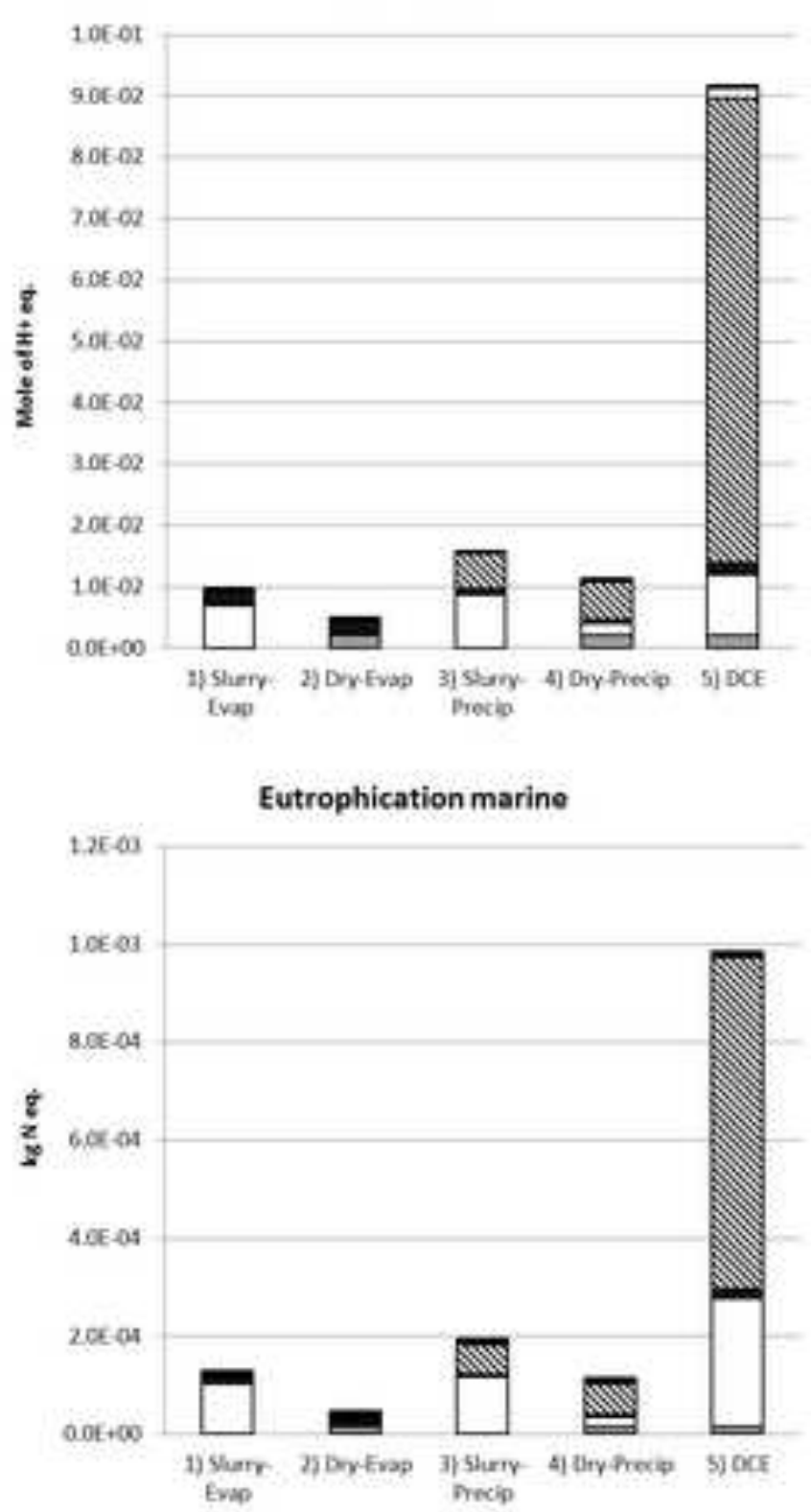

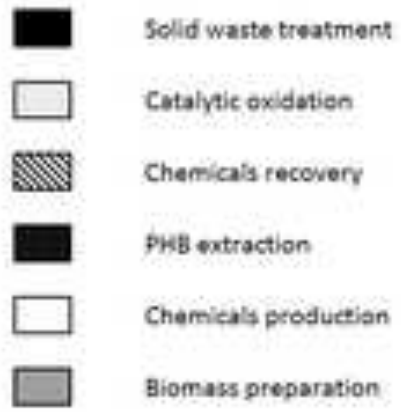


Fig. 3
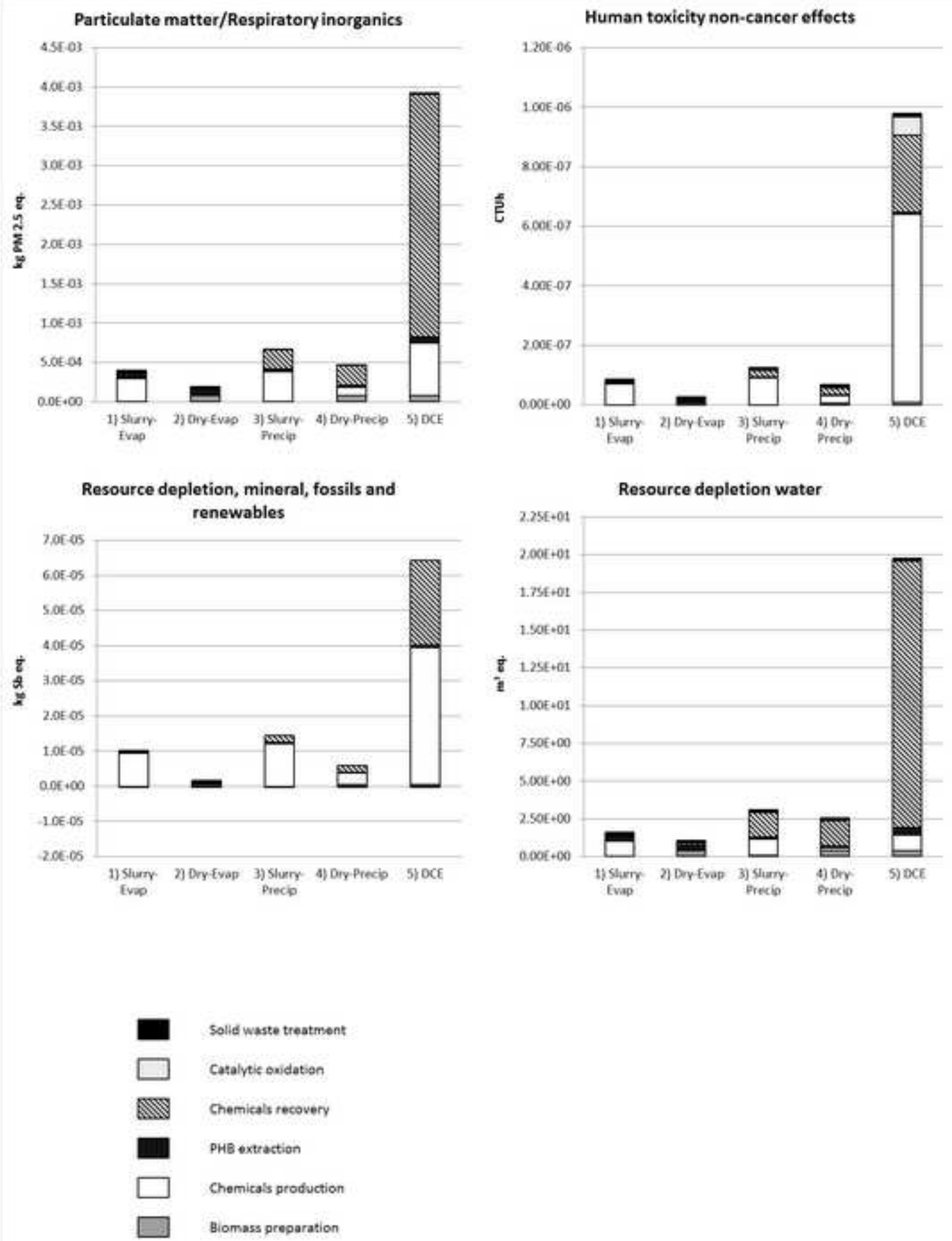
Fig. 4

Eutrophication freshwater

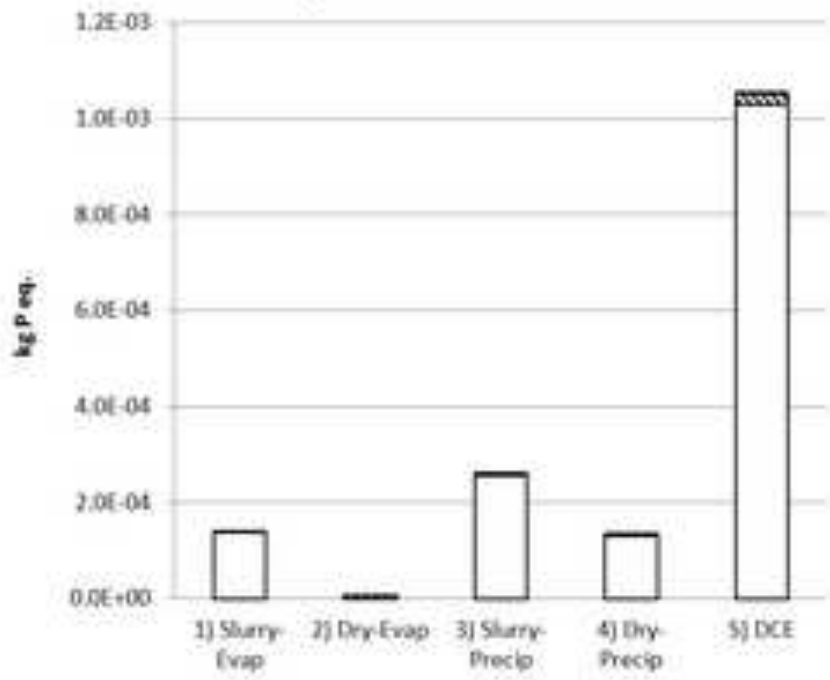

Human toxicity cancer effects

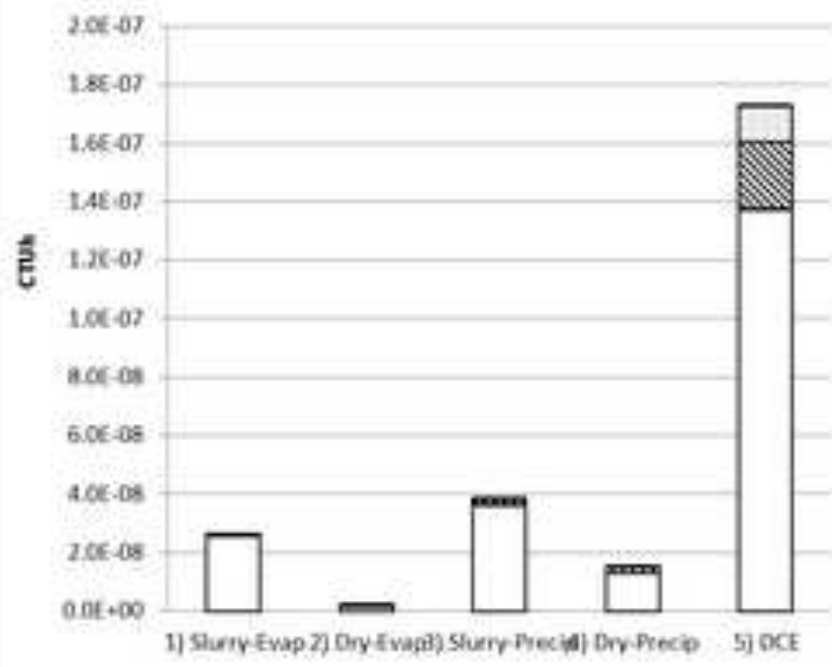

\section{Ozone depletion}

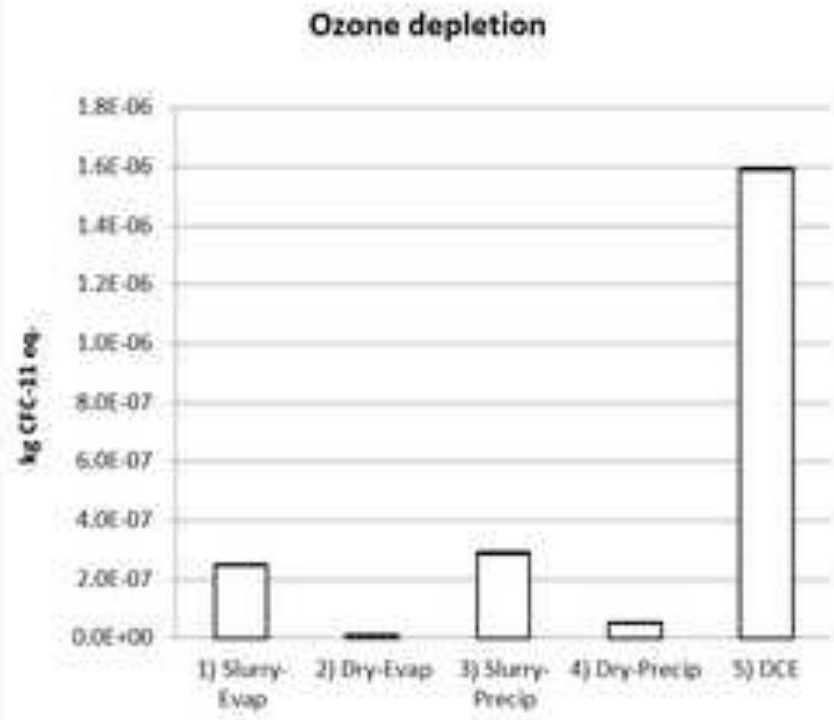

Ecotoxicity freshwater

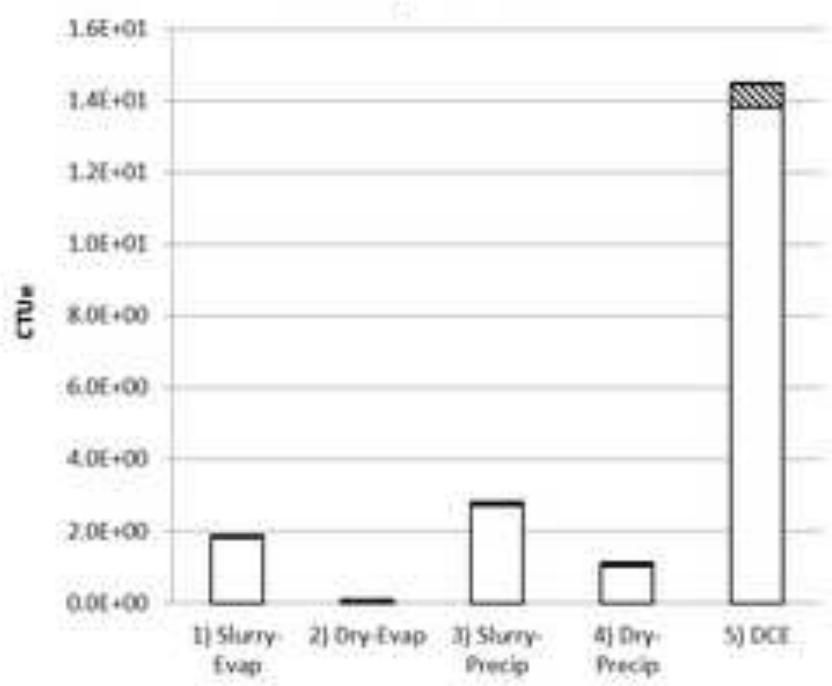

Ionizing radiation human health

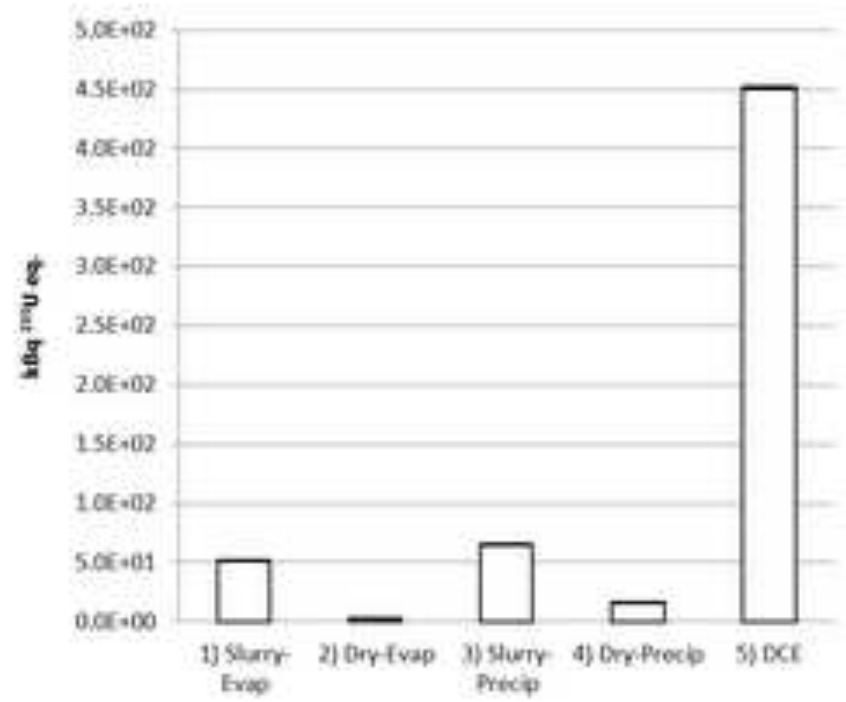

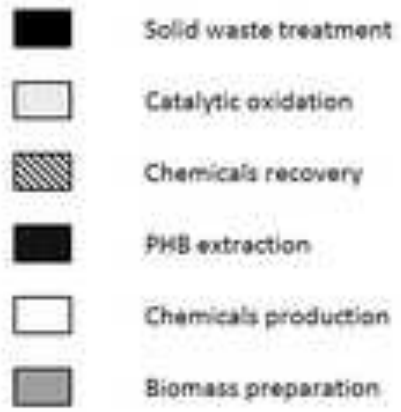

